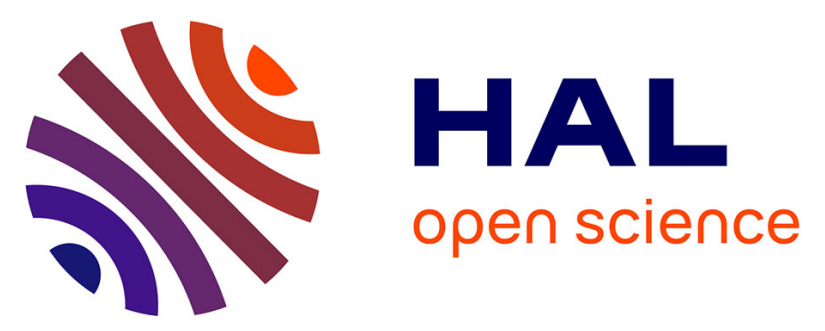

\title{
Intra-interstadial environmental changes in Last Glacial loess revealed by molluscan assemblages from the Upper Palaeolithic site of Amiens-Renancourt 1 (Somme, France)
}

Olivier Moine, Pierre Antoine, Sylvie Coutard, Gilles Guérin, Christine Hatté, Clément Paris, Ségolène Saulnier-copard

\section{To cite this version:}

Olivier Moine, Pierre Antoine, Sylvie Coutard, Gilles Guérin, Christine Hatté, et al.. Intra-interstadial environmental changes in Last Glacial loess revealed by molluscan assemblages from the Upper Palaeolithic site of Amiens-Renancourt 1 (Somme, France). Journal of Quaternary Science, 2021, Special Issue: Pleistocene geoarchaeology and palaeoenvironments in European loess, 36 (8), pp.1322-1340. 10.1002/jqs.3312 . hal-03224365

\section{HAL Id: hal-03224365 \\ https://hal.science/hal-03224365}

Submitted on 6 Sep 2021

HAL is a multi-disciplinary open access archive for the deposit and dissemination of scientific research documents, whether they are published or not. The documents may come from teaching and research institutions in France or abroad, or from public or private research centers.
L'archive ouverte pluridisciplinaire HAL, est destinée au dépôt et à la diffusion de documents scientifiques de niveau recherche, publiés ou non, émanant des établissements d'enseignement et de recherche français ou étrangers, des laboratoires publics ou privés. 
1 Intra-interstadial environmental changes in Last Glacial loess revealed by molluscan

2 assemblages from the Upper Palaeolithic site of Amiens-Renancourt 1 (Somme, France)

4 A molluscan record depicts intra-interstadial environmental phases

* Corresponding author

KEYWORDS: Terrestrial molluscs, Loess, Upper Weichselian, Interstadial, Upper Palaeolithic

ABSTRACT: The Amiens-Renancourt 1 site recently yielded one of the most important Upper Palaeolithic Human occupations of northern France by the number of flint artefacts and especially by the presence of Venus figurines. All the material comes from a single archaeological layer located in a tundra gley bracketed by loess units. A multi-proxy study combining a detailed stratigraphy, luminescence and radiocarbon datings and high-resolution $(5 \mathrm{~cm} /$ sample) grain size and molluscan analyses was therefore carried out to reconstruct and date the associated environmental changes and to determine the exact context of the Human occupation. The chronological frame thus established supports the correlations of the archaeology-bearing tundra gley and of an underlying arctic brown soil with Greenland interstadials GI-4 and GI-3. Composition changes in the molluscan population enabled the identification of transitional and optimum phases and sub-phases within these two pedogenetic horizons. A conceptual correlation model linking molluscan phases with millennial-timescale variations of Greenland ice-core and Sieben Hengste speleothem climate records is proposed. The Human occupation appears contemporaneous to the end of the stadial-interstadial transition of GI-3. Synchronous in Amiens-Renancourt 1 and Nussloch, subsequent micro-gleys may also result from a regional/global forcing. Such a level of detail is unprecedented in a loess sequence. 


\section{Introduction}

In continental Europe, only a few (sub)continuous speleothems and sedimentological, pollen and diatom records from lacustrine and peat deposits document the environmental impact of the millennial-timescale milder oscillations, i.e. interstadials, of the last glacial period (Weichselian) north of the Mediterranean domain (Ampel et al., 2010; Luetscher et al., 2015; Fankheuser et al., 2016; Sirocko et al., 2016; Duprat-Oualid et al., 2017).

Conversely, loess deposits cover vast areas in European plains (Lehmkuhl et al., 2021) and offer numerous sequences showing alternations of loess units and pedogenetic horizons, i.e. tundra gleys or arctic/boreal brown soils (Antoine et al., 2001, 2013, 2014; Jary \& Ciszek, 2013; Meszner et al., 2013; Haesaerts et al., 2016; Zens et al., 2018), which respectively deposited during stadials and formed during interstadials (Antoine et al., 2009). This scheme is particularly well-expressed between 35 and $20 \mathrm{ka}$ owing to high sedimentation rates, i.e. about $1 \mathrm{~m} / \mathrm{ka}$, and supported by radiocarbon chronologies derived from classical (charcoal, bones, terrestrial mollusc shells) or new (earthworm calcite granules, $n$-alkanes) dating materials (Haesaerts, 2009; Moine et al., 2017; Újvári et al., 2017; Zech et al., 2017).

Contrary to pollen, terrestrial mollusc shells are present in most European loesses (Ložek, 1990). Their 5-40 \% calcium carbonate $\left(\mathrm{CaCO}_{3}\right)$ content (Bosq et al., 2020) favoured both shell construction and preservation, but also the preservation of bone remains in Human occupation layers as well. As assemblages of these organisms are highly sensitive to their medium, they are well-suited to reconstruct millennial timescale palaeoenvironmental changes (e.g. Moine et al., 2008, 2011; Sümegi et al., 2019). They thus provide a useful complement to the chronostratigraphical frame for Middle and Upper Palaeolithic sites of northern France (Antoine et al., 2016).

Continuous molluscan records compiled for the $35-20 \mathrm{ka}$ period revealed a similar environmental response to stadial-interstadial cycles across western Europe. Increases in both the total abundance of molluscs and the proportions of hygrophilous and palustral species respectively indicate warmer and more humid conditions during the formation and degradation of tundra gley horizons (Remy, 1969; Kerney, 1971; Schiermeyer, 2000; Moine et al., 2008, 2011). The disappearance of the most vegetation-requiring taxa systematically leads to a richness minimum at the top of tundra gleys interpreted as a harmful effect of ground ice on vegetation (Moine, 2014). In northern France, due to the poor mollusc diversity, this effect is less marked and a few species may even briefly appear at the basis of tundra gleys, indicating a short phase of vegetation improvement following harsh stadial conditions.

The Amiens-Renancourt 1 site offered us a new opportunity to document environmental changes associated with stadial-interstadial cycles with a time resolution rarely reached until now but which is necessary to characterise features specific to each cycle and event. This site also yielded the youngest Gravettian occupation of northern France preceding the abandonment of the region during the Last Glacial Maximum (LGM) (Antoine et al., 2016). Its study will thus also allow for the precise positioning of the archaeological layer in its climatic and environmental context.

This is thus a fundamental test to demonstrate that such an approach may improve correlations between archaeological layers and regional or global climate and environmental 
records. Such correlations basically rely on the relative - by typology - or absolute - by radiocarbon or thermoluminescence - dating of the archaeological material, especially when the stratigraphy has been reworked, is unclear or complex and environmental proxies are absent or inconclusive. However, combining high resolution palaeoenvironmental information from bioindicators for open air sites located in clearly stratified loess sequences may allow much more precise correlations. Reaching the expected (multi-)centennial-timescale will definitely deepen the comprehension of the relationships between climate and human settlements in the European Plain during the last glacial period.

\section{Site settings}

The archaeological site of Amiens-Renancourt 1 is located in northern France (Fig. 1) at the edge of the western suburb of Amiens in the Renancourt district (49 54'5.21"N; $\left.2^{\circ} 15^{\prime} 50.58^{\prime \prime} \mathrm{E}\right)$. The excavation is located on the left-hand side of the Somme River valley, several meters above the level of its present alluvial plain, at the foot of the north exposed slope of a slight promontory separating the Grâce dry valley from the Selle River valley (Fig. 2).

The most complete loess succession is 6.75 -m-thick and overlies a chalky flint gravel bed reached at a depth of $8.3 \mathrm{~m}$ using a manual auger (Fig. 3). No Quaternary sediments are found below this gravel bed. It overlies the bedrock constituted of Upper Cretaceous chalk outcropping westward at short distance and constituting the promontories that separate the different valleys (Kuntz \& Dupuis, 1972).

The first archaeological discoveries in the surroundings date back to the beginning of the $20^{\text {th }}$ century (Commont, 1913) owing to the numerous brickearth quarries in operation at that time. A concentration of Palaeolithic flint artefacts and large mammal bone remains was excavated on this occasion in the former Devalois quarry, but then lost. Fortunately, a new concentration, named Amiens-Renancourt 1, was discovered in 2011. Excavated every year since, the archaeological layer has already yielded many horse bone fragments, thousands of lithic remains attributed to the Recent-Final Gravettian technocomplex as well as ornamental items and several Venus figurines in chalk (Paris et al., 2017, 2019).

Based on these archaeological discoveries, Amiens-Renancourt 1 is thus one of the best preserved and most important Gravettian sites for northern France (Paris, 2020), and is even unique regarding the presence of Venus figurines. It is clearly positioned in the stratigraphy, almost undisturbed and with a very limited vertical dispersion. The high-resolution palaeoenvironmental study of this site, along with an adequate chronology, will thus contribute to documenting the impact of the millennial-timescale climate variability on continental loess environments and to exploring their relationship with this Human settlement.

\section{Material and methods}

\section{Sampling strategies}

The studied profile was positioned on a side of the excavated area so that it passes through the archaeological layer, which can be optimally associated with palaeoenvironmental proxies. 
After a careful cleaning of the profile, a precise drawing of the sequence was made at the scale 1:20 annotated with pedostratigraphic features and the position of all the samples (Fig. 3). Following the continuous column sampling (CCS) established by Antoine et al. (2009), 48 samples were collected for grain size analyses by cutting successive 5 -cm-thick and 200-g-large slices of sediment, as well as 44 5-cm-thick and 10-litre-large samples for molluscan analyses taken side by side in parallel (Fig. 3) for precise comparisons. Samples (H: -60/-65, H: $-65 /-70, \mathrm{H}:-70 /-75)$ located at the base of the upper profile close to and within the archaeological layer were taken afterwards during the excavation of the square crossed by the profile. As their volume was respectively 30, 20.25 and 16.80 litres of sediments, their molluscan abundances were normalised to 10 litres to be comparable with those of the other samples.

In addition, 6 samples were taken for optically stimulated luminescence (OSL) datings using copper cylinders $(\mathrm{L}=14 \mathrm{~cm}, \varnothing=3.5 \mathrm{~cm})$ hammered horizontally into the sediment. After extraction they were sealed at both ends to prevent exposure to light. To measure dosimetric parameters, about $2 \mathrm{~kg}$ of the sediment were taken for each sample in a radius of $30 \mathrm{~cm}$ around each cylinder. Ten radiocarbon (hereafter ${ }^{14} \mathrm{C}$ ) datings were also performed on samples of earthworm calcite granules (hereafter ECG) extracted from molluscan samples following the methodology of Moine et al. (2017) to complete the four obtained on bone, burnt bone and charcoal fragments from the archaeological layer (Paris et al., 2013, 2017). All dating samples were distributed throughout the record to constrain the age of the archaeological layer and of the main pedostratigraphic horizons of the studied part of the sequence.

\section{Analytical protocols}

\section{Granulometry}

Grain size analyses were performed on 2 to $5 \mathrm{~g}$ homogenised samples using a Beckman Coulter LS1330XR laser particle size analyser. The samples were first dispersed by sodium hexametaphosphate ( $5 \%$ ) during a period of one night in a rotating agitator, and then sieved at $160 \mu \mathrm{m}$ to remove the coarse fraction including non-sedimentary Fe-Mn concretions, calcified roots and shell fragments that may bias the analysis. The coarse fraction was dried and weighed. For the decarbonated analyses, carbonates were removed using $\mathrm{HCl}(4 \%)$ until the effervescence subsided. Then 1 to $2 \mathrm{ml}$ of $\mathrm{HCl}(20 \%)$ was added to check that the reaction was complete. The samples were rinsed by centrifugation before dispersion. Finer fractions were measured on the analyser at least three times to ensure good reproducibility. The limits of the grain size classes (clay: $\leq 6 \mu \mathrm{m}$; coarse silts: $20-61 \mu \mathrm{m}$; fine sands: 61 $160 \mu \mathrm{m}$ ) were adjusted using the comparison between classical sieve-pipette and laser grain size analyses for a set of test samples from the loess sequence of Havrincourt about $60 \mathrm{~km}$ to the north-east (Antoine et al., 2014). The grain size index (hereafter GSI) defined as the ratio between coarse silts and fine silts plus clay (Rousseau et al., 2002), which is sensitive to minor changes in the loess deposition dynamics, was calculated for the characterization of millennial-timescale climate changes, using class size limits defined for the laser particle size analyser (Antoine et al., 2009). 


\section{Luminescence dating}

Luminescence analyses were performed on the fine $(4-11 \mu \mathrm{m})$ quartz fraction. Preparation techniques followed usual procedures (Lang et al., 1996) and aliquots were prepared by settling of a $1 \mathrm{mg} / \mathrm{ml}$ suspension on $10 \mathrm{~mm}$ diameter stainless steel discs. The final quartz deposit was about $1 \mathrm{mg} / \mathrm{cm}^{2}$. All luminescence measurements were performed using a Risø TL/OSL-DA-15 system equipped with blue $(470 \mathrm{~nm})$ light-emitting diodes and an IR $(830 \mathrm{~nm})$ laser diode (Bøtter-Jensen et al., 2002). The luminescence signals were detected through a $7.5 \mathrm{~mm}$ thick Hoya U-340 filter. Irradiations were performed with the ${ }^{90} \mathrm{Sr} /{ }^{90} \mathrm{Y}$ source of the TL-OSL reader (dose-rate on 01/01/2015 was $0.132 \mathrm{~Gy} / \mathrm{s}$ ).

The determination of equivalent doses was achieved using a single-aliquot regenerative-dose (SAR) procedure (Murray \& Wintle, 2000). We used a measurement protocol identical to the SAR datings of quartz from Havrincourt loess (Guérin et al., 2017) as all samples have an OSL behaviour close to those of this site. Thus, the parameters of the SAR protocol were fixed individually for each sample so as to satisfy the preheat plateau test performed for preheat temperatures ranging from 180 to $320^{\circ} \mathrm{C}$ with $20^{\circ} \mathrm{C}$ steps. For all samples it was checked that the recycling ratio was unity within a few percent as well as the dose recovery test (Murray \& Wintle, 2003). The alpha efficiency factor was set to $0.0420 \pm 0.0020$, the mean value measured on quartz from Havrincourt loess.

Annual dose rates were calculated using the data in table 1 and the last revised conversion factors (Guérin et al., 2011). The contribution of cosmic rays was calculated using the depth from the surface and a sediment density of 2 (Prescott \& Hutton, 1994). U, Th and K concentrations were measured on the sediment samples taken around the OSL cylinders. Prior to gamma spectroscopy, the sediment was dried for 3 days at $105^{\circ} \mathrm{C}$. Th and $\mathrm{K}$ activities were calculated using the specific activities of ${ }^{234} \mathrm{Th},{ }^{228} \mathrm{Ra}$ and ${ }^{40} \mathrm{~K}$, the latter only used for $\mathrm{K}$. The water saturation content was measured for each sample and the incidence of moisture was calculated by assuming a mean water content of the sediment since its deposition between 60 and $100 \%$ of the saturated value (Aitken, 1985).

\section{Radiocarbon dating}

For the archaeological layer, four samples (two bones, one burnt bone and one charcoal) were carefully selected for radiocarbon dating. Earthworm calcite granules were also selected following the protocol of Moine et al. (2017). For each molluscan sample, the 50 selected granules $(0.8<\varnothing<1 \mathrm{~mm})$ provided between 50 and $70 \mathrm{mg}$ of $\mathrm{CaCO}_{3}$. Radiocarbon measurements were performed in Poznan, Saclay and Lyon radiocarbon laboratories (Tab. 2). From the basal auger sediment sample, 3 granules were extracted for each of the three aliquots, providing between 1.1 and $1.51 \mathrm{mg}$ of $\mathrm{CaCO}_{3}$. Given the small volume of the sediment sample, the minimum size limit of selected granules was lowered to $0.5 \mathrm{~mm}$. They were treated at LSCE, Gif-sur-Yvette (GifA/ECHo prefixes as chemistry ID and measurement ID respectively) according to the same chemical protocol. $\mathrm{CO}_{2}$ evolved from carbonate acid attack was collected and flame-sealed in Pyrex tubes. Physical measurement was handled on the $\mathrm{CO}_{2}$ gas itself (no graphitization step) by ECHoMICADAS (Synal et al. 2007; TisnératLaborde et al., 2015) through the gas source (Ruff et al., 2007). This procedure makes it possible to measure samples as small as some dozens of micrograms of carbon. 
210 Sediment samples taken for the molluscan analysis were wet sieved on a $425 \mu \mathrm{m}$ mesh and then dried. All useful shells and fragments were sorted, identified, counted and stored. The number of individuals per taxa was estimated according to Ložek (1964). Taxonomic attributions were based on Welter-Schultes (2012), the results of Nekola et al. (2015) for Pupilla species and the latest additions to the MolluscaBase (https://molluscabase.org/), and the ecological classification of taxa followed the groups established by Ložek (1964) and Puisségur (1976).

\section{Results}

\section{9}

220

\section{Stratigraphy and sedimentology}

According to the field description (Fig. 3), five sub-sequences can be distinguished:

- Sub-sequence I (unit 13 to 12) is made of loessic material partly reworked by hillwash processes and accumulated at the foot of the slope directly on the chalk bedrock, testifying to the occurrence of a major erosion event directly preceding the deposition of the first sandy loess of unit 13. The decreasing content in chalk granules and gelifracted flint fragments from the base to the top suggests that the contribution of the bedrock, eroded on the overlooking plateau, progressively decreased with the increasing loess cover deposition in the area. Unit 12 features are characteristic of a tundra gley horizon;

- Sub-sequence II (unit 11 to 6) is made of homogeneous loess units alternating with a weakly developed arctic brown soil (unit 10), a tundra gley (unit 8) and two micro-gleys. Its lower boundary is marked by the onset of both high GSI values and of an increasing trend in clay, suggesting an enhanced contribution of aeolian deposition processes (Fig. 4). In the absence of a synchronous GSI decrease, the decrease in fine sand percentage in the middle of unit 11 associated with the disappearance of sandy layers probably indicates the end of hillwash processes. A few meters away from the profile, unit 10 turns into a tundra gley horizon. Locally, its brownish facies may thus result from a better drainage favouring oxidation processes owing to a steeper slope. This recalls the BS5 units described at Ringen as an "intermediated tundra gley/boreal soil" (Zens et al., 2018). The archaeological layer is in the median part of the tundra gley (unit 8). Each of these two horizons is characterised by fine sand and GSI decreases with minima occurring $5-10 \mathrm{~cm}$ below the surface of unit 10 and 10 $15 \mathrm{~cm}$ above that of unit 8 . Slight decreases in the fine sand percentage are associated with the micro-gley located in the middle of unit 7 and in the thin upper tundra gley horizon (unit 6), whereas GSI values respectively show a plateau and an increase;

- Sub-sequence III (unit 5 and 4) is made of laminated sandy loess with cryo-desiccation micro-crack levels corresponding to small $(\varnothing \sim 20-30 \mathrm{~cm})$ polygons. Its sharp lower boundary and the associated GSI increase (Fig. 4) highlight a rapid change toward a stronger loess deposition dynamics;

- Sub-sequence IV (unit 3 and 2) is made of homogenous loess. It began with an erosive humid and cold event marked by a humic tundra gley in which one ice-wedge cast was 
observed. The loess deposition dynamics reverts to similar conditions to those prevailing during sequence II, albeit much more stable;

- Sub-sequence V (unit 1 and 0 ) is made of two horizons belonging to the Lateglacial/Holocene soil complex strongly eroded by anthropogenic processes (agriculture).

\section{Chronology}

Distributed from the top of unit 12 to the top of unit 7, ECG ${ }^{14} \mathrm{C}$ ages range from 40926 45484 to 26036-26929 cal BP without inversions (Tab. 2; Fig. 4). Scattered between 4092645484 and $30667-31646$ cal BP, the three ages provided by the three small aliquots of the lowermost sample indicate that ECG of different ages were gathered along the slope by reworking processes. The younger one provides a minimum age estimate of the reworking phase. Such a mix explains the gap of about $6 \mathrm{ka}$ that separates both ages from unit 11 . The two lowermost ages of column B and the two oldest ones of the auger sample were therefore rejected. The ${ }^{14} \mathrm{C}$ age obtained on earthworm calcite granules in the archaeological layer is in very good agreement with those obtained on burnt bone and charcoal. This demonstrates the reliability of this material for ${ }^{14} \mathrm{C}$ datings in loess contexts from north-western Europe. The other two ages obtained on bone appear significantly younger (no recovery between their $2 \sigma$ age ranges and that of the ECG ${ }^{14} \mathrm{C}$ of the archaeological layer). Such shifts between ages obtained from different materials of a unique layer often occur in archaeological contexts. They may result from the quality of the samples or from the dated carbon fraction, which depends on the nature or the preservation state of the samples. The two ${ }^{14} \mathrm{C}$ ages (Lyon-632 and Lyon-633) obtained on an isolated bone found in a test pit in 1997 about $100 \mathrm{~m}$ SE of the excavation site (Fagnart et al., 2013) demonstrate the occurrence of erosional events and hillwash processes during the deposition of the thick laminated loess of sequence III. The topographically higher position of this bone also suggests an occupation of the area by prehistoric humans that largely exceeded the limits of the excavation. According to the uppermost ${ }^{14} \mathrm{C}$, i.e. 26036-26929 cal BP, sequence II should end around 26.5-26 ka. Statistically different, the ${ }^{14} \mathrm{C}$ ages obtained in unit 10 and 8 confirm the occurrence of two independent pedogenic phases.

Distributed between units 13 and 7, OSL ages range from $31.0 \pm 1.6$ to $27.2 \pm 1.5 \mathrm{ka}$ (Tab. 1). Both ${ }^{14} \mathrm{C}$ and OSL age ranges are thus in good agreement. The uppermost one, i.e. REN1 14$03(27.6 \pm 1.4 \mathrm{ka})$, is slightly younger than the closest ${ }^{14} \mathrm{C}$ age of sample $\mathrm{H}:-15:-10$ (2603626929 cal BP), though this difference is not statistically significant. Nor is the apparent shift of the youngest OSL age of the archaeological layer, i.e. REN1 14-04 (27.2 $\pm 1.5 \mathrm{ka})$, which takes the error bars into account. The discrepancy is greater for the OSL age located in unit 13. Sample REN1 15-01 appears significantly younger than sample REN1 14-02 located above (Tab. 1). However, its water content $(23.3 \pm 2.3 \%)$, which is significantly lower than that of all the other samples, is certainly incorrect and was therefore assumed to result from the destructuring of the sample between the field and the laboratory, leading to a decreased capacity to absorb water. Recalculated with the water content value of a physically close sample taken on another profile of the site (Fig. 3, Tab. 1), REN1 15-01* yields an age of $30.5 \pm 2.0 \mathrm{ka}$, close to that of sample REN1 $14-02$ and to the ${ }^{14} \mathrm{C}$ of sample A: $0-20$ (3066731646 cal BP). It is assumed here that the strong reworking undergone by unit 13 may have reduced its porosity and water absorption capacity, leading to younger ages. Furthermore, the 
lower positions of samples REN1 15-01* and A: 0-20 suggest a rapid deposition of reworked units 13 and 12, possibly during Greenland interstadial (GI) 5.1.

Consequently, the Amiens-Renancourt 1 loess sequence covers the period between about 31 and $22 \mathrm{ka}$. Its four main pedogenic horizons are synchronous with GI-5.1, GI-4, GI-3 and GI2 , the third one including a unique archaeological layer solidly dated around $27.5-28 \mathrm{ka}$ (Fig. 4).

\section{Malacology}

The number of individuals per assemblage (hereafter abundance) varies between 8 and 3855, and the number of taxa (hereafter richness) between 3 and 6 (Tab. 3; Fig. 5). Extreme values of both parameters are similar to those from other northern France molluscan records (Moine, 2008; Moine et al., 2011). Moreover, owing to the occurrences of Arianta arbustorum, Vallonia costata, Punctum pygmaeum and Clausilia rugosa parvula, the composition of the molluscan fauna is in agreement with the position of the site at the boundary between the western and central malacological domains (Moine, 2014). The poor diversity and the ecological preferences of the few molluscan taxa (Tab.4) almost always reflect a microenvironmental mosaic dominated by damp areas in which palustral and dry loci of variable extension occur. Moreover, the limited changes in the composition of the molluscan fauna and in taxa relative abundances (Fig. 5) indicate that the vegetation cover was most of the time discontinuous and poorly diversified, with only short phases of densification possibly accompanied by isolated patches of shrubs. However, despite the relative stability of the composition of the molluscan fauna, the thorough observation of variations in absolute and relative taxa abundances revealed the existence of four types of phases (Tab. 5) succeeding in a pattern of seven cycles (C1-7) (Fig. 5).

\section{Phase I}

All the samples attributed to this type of phase are located in homogeneous (units 11,9 and 7) or laminated (unit 5) loess units. Their very low abundance rarely exceeds 100 individuals (Tab. 5, Fig. 5). As most taxa of the site are able to survive freezing temperatures down to -12 to $-15^{\circ} \mathrm{C}$ (Ansart et al., 2014), cold temperatures during the activity period most probably limited the development of the molluscan population during these phases. Indeed, rearing experiments at less than $15^{\circ} \mathrm{C}$ attempted during the cited study proved to be ineffective.

The relative abundances of dominant taxa indicate that the environmental conditions attributed to phase I differ slightly from one cycle to another. They can be rather dry (cycles C2 and C7), damp (cycles C3, C5 and C6), or well-balanced between the different components (dry, damp, palustral) of the micro-environmental mosaic (cycle C4). Although phase I molluscan faunas almost always reflect a discontinuous and poorly diversified vegetation cover, occasional occurrences of Vallonia costata indicate short phases of densification as during $\mathrm{C} 2, \mathrm{C} 4$ and $\mathrm{C} 5$.

\section{Phase II}


This type of phase is characterised by a simultaneous increase in all common taxa of the site, with a first weak ("start") sub-phase up to a few hundred individuals then a stronger ("acceleration") sub-phase up to several thousands. Moreover, as the hygrophilous species Succinella oblonga reacts more promptly and slightly more intensively than the others, it always predominates in phase II. The "start" sub-phase is common to all cycles from C2 to C6. It occurs at the top of loess units underlying the main pedogenic horizons in the full cycles $\mathrm{C} 3$ and $\mathrm{C} 4$, and in the micro-gleys and thin tundra gley of the incomplete cycles $\mathrm{C} 2$, C5 and C6. Although dominated by the palustral species P. alpicola, the sample of the uppermost micro-gley was included in phase II of cycle C6 given its $40 \%$ of S. oblonga and low abundance. The "acceleration" sub-phase occurs only in the full cycles C3 and C4 and is located at the basis of the main pedogenic horizons (units 10 and 8).

In the full cycle C3, the "acceleration" sub-phase is also characterised by the appearance of the mesophilous species Trochulus hispidus and the presence of Clausilia rugosa parvula and Punctum pygmaeum, two vegetation-demanding species, which all benefit from the moderate moisture increase. In cycle C4, only Trochulus hispidus is present. During the "start" subphase of cycle C5 Clausilia rugosa parvula briefly occurs with half-forested species Arianta arbustorum. The richness thus increases from phase I to phase II. Consequently, both the increases in abundance and the progressive predominance of S. oblonga indicate a two-step increase in both temperature and moisture throughout phase II. A damp micro-environmental mosaic develops in which wet loci extend and the vegetation cover densifies including a few shrub patches during the "acceleration" sub-phase or from the "start" sub-phase.

In the uppermost sample of phase II in cycle $\mathrm{C} 4$, the taxa relative abundance remains the same as in the underlying one also included in the "acceleration" sub-phase, despite a sudden drop in species abundances. Contemporaneous to the dense archaeological layer, this abundance drop rather results from anthropic effects (trampling, etc.) than from a marked temperature decrease in such an improved climatic context.

\section{Phase III}

This phase occurs in the full cycles $\mathrm{C} 3$ and $\mathrm{C} 4$, and also possibly in cycle $\mathrm{C} 1$. In cycle $\mathrm{C} 3$, a "humid" sub-phase precedes a "dry" one. In the "humid" sub-phase, the total abundance is maximum and richness decreases mostly due to the disappearance of the vegetationdemanding taxa that appeared in phase II. P. alpicola prevails as it increases slightly more than slugs and P. muscorum. S. oblonga begins to decrease, slightly in C3 but much more in $\mathrm{C} 4$, i.e. in the sample overlying the archaeological layer. However, it remains unclear here whether this strong decrease results from environmental conditions or from the incapacity of S. oblonga to recolonize this anthropized area as all other dominant taxa return to almost the same level of abundance as before the Human occupation. During the "dry" sub-phase, the total abundance remains maximum, as P. muscorum, which predominates, and slug increases compensate the decreases in S. oblonga and P. alpicola. T. hispidus increases significantly but none of the vegetation-demanding taxa reappear.

Phase III occurs only in the arctic brown soil (unit 10) and in the tundra gley (unit 8). It is characterised by milder temperatures in $\mathrm{C} 3$ than in $\mathrm{C} 4$ and by a damp micro-environmental mosaic. During the "humid" phase, the extension of wet loci was maximum and more 
prominent in $\mathrm{C} 4$ than in $\mathrm{C} 3$. This is coherent with the typical reduced facies of the tundra gley (unit 8) inherited from the waterlogging of the active layer which was less well drained than during the formation of the arctic brown soil (unit 10). During the "dry" sub-phase, most of the damp areas turn to dry ones, which become prominent, whereas wet loci only slightly regress. In the absence of aquatic taxa and of a marked micro-topography, the succession of a seasonal thaw followed by a drier phase during the activity period appears more probable than the persistence of localized water ponds or releases in a drier landscape to explain the persistence of wet loci. During both sub-phases, the vegetation remains discontinuous and poorly diversified, owing to the harmful effects of waterlogging and ice lenses on plant roots, as in other tundra gley horizons (Moine, 2014).

\section{Phase IV}

This phase only follows phase III in the full cycles C1, C3 and C4. As all taxa decrease, the total abundance drops strongly but remains above 500 individuals in most of the samples. As slugs decrease less sharply, their proportions peak and the taxon sometimes prevails as in cycle C3. Phase IV of cycles C1 and C3 takes place in the upper part of geliflucted tundra gley (unit 12) and arctic brown soil (unit 10). In cycle $\mathrm{C} 1$, the micro-environmental mosaic resembles that of phase III in cycle C3 despite lower temperatures. The co-dominance of P. alpicola and P. muscorum indicate the development of a micro-environmental mosaic with both wet and dry areas. The low proportion of the hygrophilous species S. oblonga suggests that water is restrained in delimited loci or in time, e.g. during the seasonal thaw, which fits with the geliflucted facies of unit 12. Though scarce, the occurrence of Pisidium sp. suggests at least temporary local ponds. As for the brief occurrence of V. costata, it indicates an increase in the herbaceous component of the vegetation cover in dry areas. In cycle C3, the micro-environmental mosaic appears well-balanced between dry, damp and wet areas. However, the vegetation remains sparse despite a moderately moist and stable soil resulting from a higher clay content which favoured the development of slugs.

Phase IV of cycle C4 takes place at the base of the homogeneous loess (unit 7) directly overlying the tundra gley (unit 8). The molluscan fauna reflects a cooling context and a damp micro-environmental mosaic in which wet loci tend to disappear. Only a slight increase in the herbaceous component is indicated by a brief occurrence of $V$. costata in the basal sample. This environmental trend is contrary to that observed in phase II. The presence of Pisidium sp. suggests the persistence of temporary ponds in the surroundings. Despite relatively high temperatures, the moderate moisture increase, the absence of water-driven sedimentological features and the resumption of loess deposition underline the limited seasonal water release but its possibly longer persistence during the activity period of the previous phase III.

\section{Discussion}

\section{Stadial-interstadial cycles}

The 5-cm sampling resolution of the Amiens-Renancourt 1 molluscan record provides a new opportunity to confirm the conceptual model linking palaeoenvironmental changes associated with loess-tundra gley alternations with Weichselian Upper Pleniglacial stadial-interstadial 
cycles (Antoine et al., 2009) based on the combination of high resolution stratigraphy, grain size (Antoine et al., 2001; Rousseau et al., 2002) and molluscan (Moine et al., 2008) analyses at Nussloch (Rhine Valley, Germany). The correlation of large abundance increases, which occur in tundra gley horizons and imply milder temperatures, with interstadial phases (Moine et al., 2008) was recently confirmed by radiocarbon datings (Moine et al., 2017). Conversely, all low abundance samples from loess units were linked with stadial phases.

Furthermore, by combining the intra-interstadial environmental succession reconstructed from the molluscan record and its chronological frame, a correlation is proposed between molluscan phases and major variations of several high-resolution global and regional climate records. NorthGRIP (NGRIP) $\delta^{18} \mathrm{O}$ and calcium ion concentrations $\left(\left[\mathrm{Ca}^{2+}\right]\right)$, hereafter dust concentration, in ice core records mostly reflect local temperature and atmospheric dust loading respectively (Rasmussen et al., 2004), whereas the Sieben Hengste (7H) speleothem $\delta^{18} \mathrm{O}$ record reflects the balance between moisture reaching the site directly from the North Atlantic and by crossing the Alps from the south (Luetscher et al., 2015). Indeed, at the depth of the site ( $215 \mathrm{~m}$ below the ground surface), the temperature was assumed to be constant and $\delta^{18} \mathrm{O}$ variations to result from precipitation isotope values, i.e. provenance. Luetscher et al. (2015) also pointed out that since the North Atlantic is the main moisture source in the northern Alps, the total moisture amount increases with its proportions.

\section{Phase I}

According to the cold temperatures implied by its low molluscan abundances, phase I is linked with stadials (Fig. 7). The molluscan assemblages of Amiens-Renancourt 1 reflect poor and discontinuous steppe/tundra vegetation. This is in agreement with the rare pollen data in loess sequences. North-eastward, Weichselian Upper Pleniglacial pollen samples from Kesselt (eastern Belgium) indicate a grass-dominated steppe (Bastin, 1969). Southward, Weichselian Middle Pleniglacial pollen samples, from Villiers-Adam (northern France), Upper Pleniglacial being sterile, also indicate a grass dominated vegetation with rare woody taxa resembling modern Nordic tundra (Limondin-Lozouet \& Gauthier, 2003). At Amiens-Renancourt 1, owing to the low local richness, no cyclical variations of molluscan richness occur during stadials as in Nussloch, except brief occurrences of V. costata in phases I of C4 and C5 (Fig. 6). The ecological preferences of additional taxa present in Nussloch reflect a much more diversified vegetation with the presence of shrubs. The Bergsee Lake (Black Forest, Germany) pollen record shows a "steppe dominated landscape with some elements of boreal forest" during stadials, and GS-3 and GS-5.1 are distinguished by their maximum of xerophytic steppe element, i.e. Artemisia (Duprat-Oualid et al., 2017). Interestingly, the driest phases I at Amiens-Renancourt 1, i.e. in $\mathrm{C} 2$ and $\mathrm{C} 7$, are respectively correlated with these two stadials contemporaneous to HE 3 and 2 respectively, whereas at Nussloch molluscan richness maxima suggest a densification of the vegetation cover and increases in shrubs.

\section{Phase II}

Phase II, and especially its two sub-phases (start and acceleration), had not yet been precisely depicted. At Curgies (northern France), "MZ2" located at the basis of a tundra gley presents the characteristics of phase II, including a short occurrence of a vegetation-requiring species 
typical of cold and wet mountain environments, i.e. Columella columella (see Moine et al., 2011). At Nussloch, only a "MP-3" phase with higher frequencies in hygrophilous Succinella oblonga was recognized (Fig. 6) and occurred within all tundra gley horizons and microgleys. Increases in the proportions of S. oblonga also preceded the high abundance "MP-0" phases at the basis of both G3 and G4 tundra gleys. It must be kept in mind here that hydromorphic processes leading to gley formation are linked to the functioning of a permafrost active layer and develop mainly downward in previously deposited sediments (Antoine et al., 2009). This can explain the apparent discrepancy between the two phases II taking place at the base of tundra gleys at Nussloch and in underlying loess at AmiensRenancourt 1 . Hence, as the large molluscan abundance increase occurs only during the "acceleration" sub-phase, "start" sub-phases are correlated with small excursions of $7 \mathrm{H} \delta^{18} \mathrm{O}$ towards less depleted values contemporaneous to limited NGRIP dust concentration decreases that precede GI-4 and GI-3 but also occur within GS-3 based on ${ }^{14} \mathrm{C}$ dating. As for "acceleration" sub-phases, they are linked with a subsequent increased shift in both $7 \mathrm{H} \delta^{18} \mathrm{O}$ and NGRIP dust concentration preceding GI-4 and GI-3. Active layer annual freeze-thaw cycles probably began during the "acceleration" sub-phase given its high abundances and trend toward palustral conditions. The $7 \mathrm{H} \delta^{18} \mathrm{O}$ record also indicates a larger and earlier moisture increase before GI-4 than before GI-3. In the absence of local effects, this may explain the greater thickness of both the arctic brown soil (unit 10) at Amiens-Renancourt 1 and G3 tundra gley at Nussloch compared to the above (unit 8) and G4 tundra gleys respectively (Fig. 6). At Amiens-Renancourt 1, the untypical arctic brown soil (unit 10) also implies reduced waterlogging periods and soil moisture content, and thus a limited harmful impact of diurnal freeze-thaw cycles on plant roots (Walker \& Walker, 1991).

In addition, the richer molluscan fauna occurring in GI-4 phase II in both sites also suggest a greater lengthening of the growing season allowing for a more complex seasonal succession of vegetation resulting in an apparently more diversified micro-environmental mosaic. The occurrences of Clausilia rugosa parvula and Punctum pygmaeum in phase II of cycle C3 and C5 (only C. r. parvula for the latter) are also remarkable as original in northern France and as no other elements suggest their possible allochthonous or reworked origin in this sequence. Contrary to Arianta arbustorum and Vallonia costata, which are present eastward and southward in loess from the Paris Basin, C. r. parvula and P. pygmaeum are only known in the Rhine Valley during the Weichselian Upper Pleniglacial (Moine, 2014). Their discovery raises the question of whether they persist in cryptic refuge areas in the region or come from abroad and by which means of transport. Surprisingly, P. pygmaeum also occurs at Nussloch (Rhine Valley, Germany) only at the top of the loess underlying G3 tundra gley during the studied time interval. Otherwise, such scarce occurrences indicate cryptic populations that may have been missed elsewhere in the sequence whereas these rarer taxa were still living in the surroundings. The lack of precise knowledge on Last Glacial loess molluscan fauna still prevents any conclusion as to whether occurrences of C.r.parvula and P. pygmaeum at Amiens-Renancourt 1 result from brief passive colonization phases from the Rhine Valley by an efficient means of transport, or from active expansion phases from local cryptic refuges. Whatever the case, the development of shrub patches at Amiens-Renancourt 1 may have benefited from its position sheltered from (north-)western winds by the higher Ferme de Grâce plateau on the opposite slope of the Grâce valley (Fig. 2). 
In all Weichselian Upper Pleniglacial loess sequences where they have been detected, large abundances characteristic of phase III (e.g. "MP-0" phases at Nussloch) only occur in thick cryoturbated tundra gley horizons or arctic brown soils (Remy, 1969; Schiermeyer, 2000; Moine et al., 2008, 2011), and never in thin micro-gleys (Fig. 6). In most cases associated with maximum proportions in hygrophilous and/or palustral taxa, they formed during the functioning of the active layer, which requires milder temperatures (Moine et al., 2008; Antoine et al., 2009). This thus supports the correlation of the different phases III with interstadial phases marked by maximum $\delta^{18} \mathrm{O}$ values and minimum dust concentration in NGRIP records (Fig. 7). Accompanying changes in the structure of the Pupilla populations support a lengthening of the activity period of snails over the year implying milder temperatures in spring, and to a lesser extent in autumn, rather than in summer (Moine et al., 2008, Moine, 2014). This is in agreement with palaeoenvironmental reconstructions from Les Echets (central-eastern France) diatom assemblages (Ampel et al., 2010) and modelling results from Flückiger et al. (2008). As already underlined above, interstadial environmental conditions did not favour the diversification of the vegetation, but at least benefited the development of Betula populations as recorded in the Bergsee Lake (Duprat-Oualid et al., 2017) but also in a tundra gley from the loess sequence of Kesselt (Bastin, 1969), most of the other tree taxa being allochthonous, e.g. Pinus (Duprat-Oualid et al., 2017).

Interestingly, the $7 \mathrm{H} \delta^{18} \mathrm{O}$ signal shifts back to its stadial level in the middle of GI-4 and GI-3. Slight decreases in NGRIP $\delta^{18} \mathrm{O}$ values occur synchronously. The shift back to stadial values follows immediately in GI-3 but occurs after a period of stability in GI-4. Both interstadials have thus their own course and different palaeoenvironmental responses. During GI-4, the decrease in North Atlantic moisture supply whereas temperatures are still high probably explains the occurrence of an additional dry sub-phase after the humid one within phase III in the arctic brown soil (unit 10). During this dry sub-phase, the dust concentration in the NGRIP ice core remains low, which fits with minimum grain size values in AmiensRenancourt 1. Owing to the strong cryoturbation of the top of thick tundra gley horizons that generally leads to their mix with the basis of the overlying loess unit (Fig. 6), this environmental phase has to our knowledge never been described up to now.

Finally, the correlation of phase III of cycle $\mathrm{C} 1$ must be considered with caution owing to the strongly cryoturbated facies of the sediment of the lowest tundra horizon (unit 12). A possible reworking of older material cannot be excluded though the composition changes in the molluscan fauna at the basis of the record appear realistic and the shells are well-preserved despite being sensitive to transport owing to their thinness.

\section{Phase IV}

As for phase III, pending phase IV is only linked with thick tundra gleys. Its large molluscan abundance decrease to minimum values reflects a strong temperature shift towards stadial levels, which obviously leads to correlating it to interstadial-stadial conditions characterised by a large decrease in the NGRIP $\delta^{18} \mathrm{O}$ record. During phase IV of cycle $\mathrm{C} 3$, the molluscan abundance decrease is significantly sharper than during phase IV of cycle $\mathrm{C} 4$, which fits the quicker $\delta^{18} \mathrm{O}$ decrease in GI-4 than in GI-3. Regarding the aeolian dynamics, the loess GSI, as 
well as the fine sand percentage (Fig. 4), at the top of the arctic brown soil (unit 10) increases in parallel to the dust concentration at the top of GI-4 (Fig. 7).

Conversely, the link is not that clear in phase IV of cycle C4 which shows an almost flat loess GSI signal, and only a slight increase in the fine sand percentage, at the top of the upper tundra gley (unit 8), whereas the dust concentration increases at the same pace at the end of GI-3 as at the end of GI-4 (Fig. 7). Other striking features are the relatively high molluscan abundance, intermediate between interstadial and stadial values, and the high proportions in hygrophilous taxa throughout this phase IV, suggesting the persistence of a moisture supply, whereas $7 \mathrm{H} \delta^{18} \mathrm{O}$ values are the same for both phases IV. Up to now, these discrepancies remain unexplained, but interestingly the same evolution characterises this transition at the top of the upper tundra gley horizon at Amiens-Renancourt 1 and at the top of G4 tundra gley at Nussloch (Fig. 6), suggesting in both sites a similar forcing that affected neither NGRIP nor $7 \mathrm{H}$ records.

\section{Early LGM interstadial-like oscillations}

Owing to the reliable and precise radiocarbon chronology, more tenuous stratigraphical horizons than loess units and arctic brown soil/tundra gleys can be correlated between Amiens-Renancourt 1 and Nussloch sequences. Indeed, careful field observations revealed the presence at Amiens-Renancourt 1 of micro-gleys (Fig. 3, unit 6 and thin diffuse horizons with oxidation stains within units 7 and 11) presenting the same features as those already described in several profiles from Nussloch, i.e. P3 (Fig. 4). There, they are characterised by GSI minima (Antoine et al., 2009) and both increases in the percentage of hygrophilous taxa and decreases in molluscan richness (Moine et al., 2008). At Amiens-Renancourt 1, this concerns molluscan cycles C5 and C6 (Fig. 5). They are marked by a slowdown in the increasing trends of both GSI and the fine sand fraction (Fig. 4), increases in the percentage of hygrophilous and to a lesser extent of palustral taxa, a decrease in molluscan richness, slight and only in C5 as it is already minimum at the top of unit 7, and slight abundance increases (Fig. 5). These features are similar to those characterising the "start" sub-phase of stadial-interstadial transitions at the beginning of full cycles associated to the arctic brown (unit 10) soil and the tundra gley (unit 8). Further east, the loess section of Krems-Wachtberg (Austria) also exhibits supernumerary micro-gleys characterised by slight decreases in GSI and middle plus coarse sand values and similar, though weaker, trends in colorimetric parameters to those of tundra gleys (Sprafke et al., 2020). According to the correlations established with Greenland climate records, the micro-gleys IV-b and IV-d of profile KW-A 2015 could be contemporaneous of unit 6 and the diffuse horizon with oxidation stains of unit 7 at AmiensRenancourt 1. In between at Remagen (Germany), recent high-resolution total organic carbon (TOC) measurements were performed along several cores drilled in a plateau loess sequence (Fischer et al., 2020). Along the thickest of these cores (REM 3), TOC increases of 0.1 to $0.3 \%$ characterised pedogenetic horizons. Based on correlations with the RP1 profile located on the edge of the plateau and dated by radiocarbon and optically stimulated luminescence, excursions 10 and 9 associated with tundra gleys could be correlated with interstadials GI 4 and GI 3 respectively. Three weaker (0.4-0.5\%) TOC excursions (8, 7 and 6) were measured between GI 3 and the Eltville tephra dated around 24.3-24.4 ka (Zens et al., 2017). Though only excursion 6 appears associated with a tundra gley, all constitute potential equivalents for 
Amiens-Renancourt and Nussloch micro-gleys, but require, as do the Krems-Wachtberg ones, direct radiocarbon dating to ensure precise correlations.

The comparison between the Nussloch GSI record and a few different ice, oceanic and continental proxy records of the Northern Hemisphere has highlighted the resemblance of their signals and suggests the occurrence of millennial-timescale variations between 28 and $20 \mathrm{ka}$. Their absence from the NGRIP $\delta^{18} \mathrm{O}$ record, though present in the dust record, indicates that climatic cycles of minor amplitude and/or limited to the mid-latitudes occurred during the first half of the Last Glacial Maximum (Moine et al., 2017). However, both proxy sensitivity and chronological model precision still hamper their discrimination. Presently, although these tenuous changes in the composition of the molluscan fauna may be considered as a response to local changes, their resemblance and contemporaneity in both sites located about $500 \mathrm{~km}$ apart, as well as the similar trends of associated loess grain size variations with NGRIP dust concentration ones (Fig. 7), rather support that they result from global mid-latitude interstadial-like climate oscillations during the early Last Glacial Maximum.

\section{Age and context of the Human occupation}

Gravettian open-air sites are rare in northern France (Paris, 2020), and some of them found in loess sequences have been discovered in brownish loam units at the base of the Weichselian Upper Pleniglacial sequence, e.g. at Havrincourt (Antoine et al., 2014). However, despite the high resolution (5-cm-thick samples) of the molluscan records, the low sedimentation rate of these horizons prevents the precise reconstruction of associated palaeoenvironmental changes. Amiens-Renancourt 1 is thus the first site for which we have both a precise stratigraphical location and a favourable context for the preservation of carbonated proxies. The ${ }^{14} \mathrm{C}$ ages obtained on various materials (charcoals, burnt bones, bones, earthworm calcite granules) support the correlation of the Amiens-Renancourt 1 archaeological layer with the GI-3 interstadial (Rasmussen et al., 2014). Furthermore, after a precise description of the palaeoenvironmental evolution of the site, the relative position of the Human occupation within the succession of molluscan phases at the end of the "acceleration" sub-phase of phase II supports its occurrence at the end of the stadial-interstadial transition, during an optimum of vegetation diversification favoured by mild temperatures and moist conditions.

\section{Conclusion}

Our study is the first attempt to combine a high-resolution $(5 \mathrm{~cm})$ molluscan study with earthworm calcite granule radiocarbon dating throughout a calcareous loess sequence encompassing two Dansgaard-Oeschger (D-O) cycles and one important Palaeolithic occupation layer. It strengthens and refines the scheme of (multi-)centennial environmental phases succeeding during both interstadials and stadials established in northern France and Nussloch (Rhine Valley, Germany), and especially the role of milder and more humid conditions that progressively set in from the end of stadials to interstadial optimums. It allows for the characterization of the environmental context of a unique archaeological layer and its exact positioning at the end of the stadial-interstadial transition of a D-O cycle, and the highlighting of interstadial-like environmental changes during the Last Glacial Maximum. 
636 In the future, such high-resolution studies of open-air sites will thus be crucial, not only to

637 better constrain the millennial-timescale environmental dynamics, but also to specify the

638 Human settlement dynamics in the cyclically changing environmental and climatic context of

639 the end of the Last Glacial in the north-western side of the European periglacial domain.

640 Indeed, compared to studies carried out in caves, such a combination of palaeoenvironmental

641 proxies and dating methods with high-resolution stratigraphy results in a better constrained

642 chronology. Consequently, this type of high-resolution approach needs to be systematically

643 applied in archaeological open-air sites presenting suitable characteristics such as a clear

644 stratigraphical succession, no or minor reworking processes, a sufficient sedimentation rate,

645 carbonated sediments, and an appropriate palaeontological content, as at Amiens-

646 Renancourt 1.

647 Owing to the diversity of facies included in the Gravettian lithic techno-complex, the precise

648 and respective chronological positioning of a maximum of well documented and typical 649 archaeological layers from open-air sites in loess sequences appears as the best way to 650 reconstruct the succession of Gravettian lithic trends that spread across the European Great 651 Plain during the ten millennia preceding the Last Glacial Maximum.

652

Acknowledgements and funding. We thank both the Poznan Radiocarbon Laboratory and the LMC14 laboratory

654 that undertook ${ }^{14} \mathrm{C}$ dating. Radiocarbon dating was supported by a CNRS project "Projets Exploratoires Premier

655 Soutien" program and by CNRS ARTEMIS calls for ${ }^{14} \mathrm{C}$ dating. The first author would like to thank Léa Roth

656 for her help in sorting the mollusc shells. The authors also thank Barna Páll-Gergely and an anonymous reviewer

657 for their helpful comments that greatly improved the initial version of the manuscript.

658

\section{Data statement}

660 The data that support the findings of this study are available from the corresponding author

661 upon reasonable request. 


\section{References}

Aitken MJ. 1985. Thermoluminescence Dating. Academic Press: London.

Ampel L, Bigler C, Wohlfarth B, et al. 2010. Modest summer temperature variability during DO cycles in western Europe. Quaternary Science Reviews 29: 1322-1327.

Ansart A, Guiller A, Moine O, et al. 2014. Is cold hardiness size-constrained? A comparative approach in land snails. Evolutionary Ecology 28: 471-493.

Antoine P, Coutard S, Guérin G, et al. 2016. Upper Pleistocene loess-palaeosol records from Northern France in the European context: Environmental background and dating of the Middle Palaeolithic. Quaternary International 411: 4-24.

Antoine P, Goval E, Jamet G, et al. 2014. Les séquences loessiques pléistocène supérieur d'Havrincourt (Pas-de-Calais, France) : stratigraphie, paléoenvironnements, géochronologie et occupations paléolithiques. Quaternaire 25: 321-368.

Antoine P, Rousseau DD, Degeai JP, et al. 2013. High-resolution record of the environmental response to climatic variations during the Last Interglacial-Glacial cycle in Central Europe: the loess-palaeosol sequence of Dolní Věstonice (Czech Republic). Quaternary Science Reviews 67: 17-38.

Antoine P, Rousseau D-D, Moine O, et al. 2009. Rapid and cyclic aeolian deposition during the Last Glacial in European loess: a high-resolution record from Nussloch, Germany. Quaternary Science Reviews 28: 2955-2973.

Antoine P, Rousseau DD, Zöller L, et al. 2001. High-resolution record of the last Interglacialglacial cycle in the Nussloch loess-palaeosol sequences, Upper Rhine Area, Germany. Quaternary International 76-77: 211-229.

Bastin B. 1969. Premiers résultats de l'analyse pollinique des lœss en Belgique. Bulletin de l'Association Française pour l'Etude du Quaternaire 18: 3-11.

Bosq M, Bertran P, Degeai JP, et al. 2020. Geochemical signature of sources, recycling and weathering in the Last Glacial loess from the Rhône Valley (southeast France) and comparison with other European regions. Aeolian Research 42: 100561.

Bøtter-Jensen L, Bulur E, Murray AS, et al. 2002. Enhancements in luminescence measurement techniques. Radiation Protection Dosimetry 101: 119-124.

Boycott AE. 1934. The Habitats of Land Mollusca in Britain. Journal of Ecology 22: 1-38.

Cameron RAD, Palles-Clark MA. 1971. Arianta arbustorum (L.) on chalk downs in southern England. Proceedings of the Malacological Society of London 39: 311-318.

Clark PU, Dyke AS, Shakun JD, et al. 2009. The Last Glacial Maximum. Science 325: 710714.

Commont V. 1913. Les hommes contemporains du Renne dans la Vallée de la Somme. Mémoires de la Société des Antiquaires de Picardie 37: 207-638. 
Duprat-Oualid F, Rius D, Bégeot C, et al. 2017. Vegetation response to abrupt climate changes in Western Europe from 45 to $14.7 \mathrm{k}$ cal a BP: the Bergsee lacustrine record (Black Forest, Germany). Journal of Quaternary Science 32: 1008-1021.

Evans JG. 1972. Land snails in archaeology. Seminar Press: London \& New York.

Fagnart JP, Coudret P, Antoine P, et al. 2013. Le Paléolithique supérieur ancien dans le Nord de la France. Mémoires de la Société Préhistorique Française 56: 197-214.

Fankhauser A, McDermott F, Fleitmann D. 2016. Episodic speleothem deposition tracks the terrestrial impact of millennial-scale last glacial climate variability in SW Ireland. Quaternary Science Reviews 152: 104-117.

Fischer P, Jöris O, Fitzsimmons KE, et al. 2020. Millennial-scale terrestrial ecosystem responses to Upper Pleistocene climatic changes: 4D-reconstruction of the Schwalbenberg Loess-Palaeosol-Sequence (Middle Rhine Valley, Germany). Catena 196: 104913.

Flückiger J, Knutti R, White JWC, et al. 2008. Modeled seasonality of glacial abrupt climate events. Climate Dynamics 31: 633-645.

Guérin G, Antoine P, Schmidt E, et al. 2017. Chronology of the Upper Pleistocene loess sequence of Havrincourt (France) and associated Palaeolithic occupations: A Bayesian approach from pedostratigraphy, OSL, radiocarbon, TL and ESR/U-series data. Quaternary Geochronology 42: 15-30.

Guérin G, Mercier N, Adamiec G. 2011. Dose-rate conversion factors: update. Ancient TL 29: $5-8$.

Haesaerts P. 2009. Climatic signature and radiocarbon chronology of Middle and Late Pleniglacial loess from Eurasia: comparison with the marine and Greenland records. Radiocarbon 51: 301-318.

Haesaerts P, Damblon F, Gerasimenko N, et al. 2016. The Late Pleistocene loess-palaeosol sequence of Middle Belgium. Quaternary International 411: 25-43.

Horsák M, Juřičková L, Picka J. 2013. Měkkýši České a Slovenské republiky. Nakladatelství Kabourek: Zlín.

Jary Z, Ciszek D. 2013. Late Pleistocene loess-palaeosol sequences in Poland and western Ukraine. Quaternary International 296: 37-50.

Kerney MP. 1963. Late-glacial deposits on the chalk of South-East England. Philosophical transactions of the Royal Society of London Series B, Biological sciences 246: 203-254.

Kerney MP. 1971. A Middle Weichselian deposit at Halling, Kent. Proceedings of the Geologists' Association 82: 1-10.

Kerney MP, Cameron RAD, Jungbluth JH. 1983. Die Landschnecken Nord- und Mitteleuropas. Verlag Paul Parey: Hamburg \& Berlin.

Kuntz G, Dupuis C. 1972. Carte géologique de la France à 1/50 000 ( $\left.n^{\circ} 46\right)$, Amiens (XXIII8). Bureau de Recherches Géologiques et Minières: Orléans. 
Lang A, Lindauer S, Kuhn R, et al. 1996. Procedures used for optically and infrared stimulated luminescence dating of sediments in Heidelberg. Ancient TL 14: 7-11.

Lehmkuhl F, Nett JJ, Pötter S, et al. 2021. Loess landscapes of Europe - Mapping, geomorphology, and zonal differentiation. Earth-Science Reviews 215: 103496.

Limondin-Lozouet N, Gauthier A. 2003. Biocénoses pléistocènes des séquences loessiques de Villiers-Adam (Val d'Oise, France) : études malacologiques et palynologiques. Quaternaire 14: $237-252$.

Ložek V. 1964. Quartärmollusken der Tschechoslowakei. Verlag der Tschechoslowakischen Akademie der Wissenschaften: Praha.

Ložek V. 1990. Molluscs in loess, their paleoecological significance and role in geochronology - Principles and methods. Quaternary International 7/8: 71-79.

Luetscher M, Boch R, Sodemann H, et al. 2015. North Atlantic storm track changes during the Last Glacial Maximum recorded by Alpine speleothems. Nature Communications 6: 1-6.

Meszner S, Kreutzer S, Fuchs M, et al. 2013. Late Pleistocene landscape dynamics in Saxony, Germany: Paleoenvironmental reconstruction using loess-paleosol sequences. Quaternary International 296: 97-104.

Moine O. 2008. West-European malacofauna from loess deposits of the Weichselian Upper Pleniglacial: compilation and preliminary analysis of the database. Quaternaire 19: 11-29.

Moine O. 2014. Weichselian Upper Pleniglacial environmental variability in north-western Europe reconstructed from terrestrial mollusc faunas and its relationship with the presence/absence of human settlements. Quaternary International 337: 90-113.

Moine O, Antoine P, Deschodt L, et al. 2011. Enregistrements malacologiques à haute résolution dans les lœss et les gleys de toundra du Pléniglaciaire weichselien supérieur : premiers exemples du nord de la France. Quaternaire 22: 307-325.

Moine O, Antoine P, Hatté C, et al. 2017. The impact of Last Glacial climate variability in west-European loess revealed by radiocarbon dating of fossil earthworm granules. Proceedings of the National Academy of Sciences of the United States of America 114: 62096214.

Moine O, Rousseau D-D, Antoine P. 2008. The impact of Dansgaard-Oeschger cycles on the loessic environment and malacofauna of Nussloch (Germany) during the Upper Weichselian. Quaternary Research 70: 91-104.

Murray AS, Wintle AG. 2000. Luminescence dating of quartz using an improved single aliquot regenerative-dose protocol. Radiation Measurements 32: 57-73.

Murray AS, Wintle AG. 2003. The single aliquot regenerative dose protocol: potential for improvements in reliability. Radiation Measurements 37: 377-381.

Nekola JC, Coles BF, Horsák M. 2015. Species assignment in Pupilla (Gastropoda: Pulmonata: Pupillidae): integration of DNA-sequence data and conchology. Journal of Molluscan Studies 81: 196-216. 
Paris C. 2020. La période du Gravettien dans la zone loessique du Nord de la France. Traditions culturelles et dynamiques de peuplement. Doctoral thesis, Université de Paris I Panthéon-Sorbonne: Paris.

Paris C, Antoine P, Auguste P, et al. 2019. Les gisements gravettiens d'Amiens-Renancourt 1 et 2 (Somme, France) : premières données palethnologiques. In Préhistoire de l'Europe du Nord-Ouest: mobilité, climats et identités culturelles XXVIIIe Congrès préhistorique de France, Amiens 30 mai - 4 juin 2016 Volume 2: Paléolithique supérieur ancien, Paléolithique final - Mésolithique, Montoya C, Fagnart JP, Locht JL (eds). Société Préhistorique Française: Paris; 97-115.

Paris C, Deneuve E, Fagnart JP, et al. 2017. Premières observations sur le gisement gravettien à statuettes féminines d'Amiens-Renancourt 1 (Somme). Bulletin de la Société Préhistorique Française 114: 423-444.

Paris C, Fagnart JP, Coudret P. 2013. Du Gravettien final dans le Nord de la France ? Nouvelles données à Amiens-Renancourt. Bulletin de la Société Préhistorique Française 110: $123-126$.

Prescott JR, Hutton JT. 1994. Cosmic ray contribution to dose rates for luminescence and ESR dating: large depths and long-term time variations. Radiation Measurements 23: 497500 .

Puisségur JJ. 1976. Mollusques continentaux quaternaires de Bourgogne. Significations stratigraphiques et climatiques. Rapports avec d'autres faunes boréales de France. Doin: Paris.

Rasmussen SO, Bigler M, Blockley SP et al. 2014. A stratigraphic framework for abrupt climatic changes during the Last Glacial period based on three synchronized Greenland icecore records: refining and extending the INTIMATE event stratigraphy. Quaternary Science Reviews 106: 14-28.

Reimer PJ, Bard E, Bayliss A, et al. 2013. IntCal13 and Marine13 Radiocarbon Age Calibration Curves 0-50,000 Years cal BP. Radiocarbon 55: 1869-1887.

Remy H. 1969. Würmzeitliche Molluskenfaunen aus Lößserien des Rheingaues und der nördlichen Rheinhessens. Notizblatt des Hessischen Landesamtes für Bodenforschung zu Wiesbaden 97: 98-116.

Rousseau DD, Antoine P, Hatté C, et al. 2002. Abrupt millennial climatic changes from Nussloch (Germany) Upper Weichselian eolian records during the Last Glaciation. Quaternary Science Reviews 21: 1577-1582.

Ruff M, Wacker L, Gäggeler HW, et al. 2007. A gas ion source for radiocarbon measurement at 200kV. Radiocarbon 49: 307-314.

Schiermeyer J. 2000. Würmzeitliche Lößmollusken aus der Eifel. Doctoral thesis, Universität Düsseldorf: Düsseldorf.

Sirocko F, Knapp H, Dreher F, et al. 2016. The ELSA-Vegetation-Stack: Reconstruction of Landscape Evolution Zones (LEZ) from laminated Eifel maar sediments of the last 60,000 years. Global and Planetary Change 142: 108-135. 
Sprafke T, Schulte P, Meyer-Heintze S, et al. 2020. Paleoenvironments from robust loess stratigraphy using high-resolution color and grain-size data of the last glacial KremsWachtberg record (NE Austria). Quaternary Science Reviews 248: 106602.

Stuiver M, Reimer PJ. 1993. Extended ${ }^{14} \mathrm{C}$ Data Base and Revised CALIB $3.0{ }^{14} \mathrm{C}$ Age Calibration Program. Radiocarbon 35: 215-230.

Sümegi P, Molnár D, Gulyás S, et al. 2019. High-resolution proxy record of the environmental response to climatic variations during transition MIS3/MIS2 and MIS2 in Central Europe: The loess-paleosol sequence of Katymár brickyard (Hungary). Quaternary International 504: 40-55.

Synal HA, Stocker M, Suter M. 2007. MICADAS: A new compact radiocarbon AMS system. Nuclear Instruments and Methods in Physics Research. Section B, Beam Interactions with Materials and Atoms 259: 7-13.

Tisnérat-Laborde N, Thil F, Synal HA, et al. 2015. ECHoMICADAS: A new compact AMS system to measuring ${ }^{14} \mathrm{C}$ for Environment, Climate and Human Sciences. $22^{\text {nd }}$ International Radiocarbon Conference 2015, Dakar, Sénégal: Books of abstracts. Université Cheikh Anta Diop, Dakar, PHYS-O.05.

Újvári G, Stevens T, Molnár M, et al. 2017. Coupled European and Greenland last glacial dust activity driven by North Atlantic climate. Proceedings of the National Academy of Sciences of the United States of America 114: 10632-10638.

Walker DA, Walker MD. 1991. History and pattern of disturbance in Alaskan arctic terrestrial ecosystems: a hierarchical approach to analysing landscape change. Journal of Applied Ecology 28: 244-276.

Welter-Schultes FW. 2012. European non-marine molluscs: a guide for species identification. Göttingen: Planet Poster.

Wessel P, Luis JF, Uieda L, et al. 2019. The Generic Mapping Tools version 6. Geochemistry, Geophysics, Geosystems 20: 5556-5564.

Zech M, Kreutzer S, Zech R, et al. 2017. Comparative 14C and OSL dating of loess-paleosol sequences to evaluate post-depositional contamination of n-alkane biomarkers. Quaternary Research 87: 180-189.

Zens J, Schulte P, Klasen N, et al. 2018. OSL chronologies of paleoenvironmental dynamics recorded by loess-paleosol sequences from Europe: Case studies from the Rhine-Meuse area and the Neckar Basin. Palaeogeography, Palaeoclimatology, Palaeoecology 509: 105-125.

Zens J, Zeeden C, Römer W, et al. 2017. The Eltville Tephra (Western Europe) age revised: Integrating stratigraphic and dating information from different Last Glacial loess localities. Palaeogeography, Palaeoclimatology, Palaeoecology 466: 240-251. 


\begin{tabular}{|c|c|c|c|c|c|c|c|c|c|c|c|c|}
\hline it / Depth & Sample & $\mathrm{U}$ (ppm) & Th (ppm) & K (\%) & W (\%) & $\mathrm{Da}$ (Gy/ka) & $\mathrm{D} \beta$ (Gy/ka) & Dy (Gy/ka) & Dcos. (Gy/ka) & Dann. (Gy/a) & $\operatorname{De}(G y)$ & Age (ka) \\
\hline $7 / 3.65 \mathrm{~m}$ & REN1 14-03 & $72 \pm 0.10$ & $8 \pm 0.1$ & $6 \pm 0$ & $4 \pm 3$ & $0 \pm 0.03$ & $1.15 \pm 0.05$ & $75 \pm 0.03$ & $13 \pm 0.01$ & $43 \pm 0.11$ & $6.95 \pm 1.41$ & $27.6 \pm 1.4$ \\
\hline $8 / 4.17 \mathrm{~m}$ & REN1 13-01 & $2.86 \pm 0.17$ & $48 \pm 0.17$ & $15 \pm 0.02$ & $32.0 \pm 3.2$ & $0.43 \pm 0.03$ & $1.19 \pm 0.06$ & $78 \pm 0.04$ & $.12 \pm 0.01$ & 12 & 0.41 & \\
\hline $8 / 4.17 \mathrm{~m}$ & REN1 14-04 & $3.26 \pm 0.18$ & $8.68 \pm 0.20$ & $1.14 \pm 0.02$ & $31.5 \pm 3.2$ & $0.47 \pm 0.04$ & $1.24 \pm 0.06$ & $0.83 \pm 0.04$ & $0.12 \pm 0.01$ & $2.65 \pm 0.13$ & $71.98 \pm 1.82$ & $27.2 \pm 1.5$ \\
\hline $9 / 4.40 \mathrm{~m}$ & REN1 14-01 & $3.00 \pm 0.18$ & $8.48 \pm 0.17$ & $1.15 \pm 0.02$ & $30.8 \pm 3.1$ & $0.45 \pm 0.03$ & $1.22 \pm 0.06$ & $0.80 \pm 0.04$ & $0.12 \pm 0.01$ & $2.59 \pm 0.12$ & $3.49 \pm 1.63$ & $8.4 \pm 1.5$ \\
\hline $11 / 5.10 \mathrm{~m}$ & REN1 14-02 & $2.82 \pm 0.18$ & $8.68 \pm 0.20$ & $1.17 \pm 0.02$ & $30.6 \pm 3.1$ & $0.44 \pm 0.03$ & $1.21 \pm 0.06$ & $0.80 \pm 0.04$ & $0.11 \pm 0.01$ & $2.56 \pm 0.12$ & $79.25 \pm 1.67$ & $31.0 \pm 1.6$ \\
\hline $13 / 6.30 \mathrm{~m}$ & REN1 15-01 & $2.61 \pm 0.19$ & $8.07 \pm 0.08$ & $1.18 \pm 0.02$ & $23.3 \pm 2.3$ & $0.43 \pm 0.03$ & $1.26 \pm 0.05$ & $0.80 \pm 0.03$ & $0.12 \pm 0.01$ & $2.61 \pm 0.11$ & $68.42 \pm 1.86$ & $26.2 \pm 1.3$ \\
\hline $13 / 6.30 \mathrm{~m}$ & REN1 15-01* & $2.61 \pm 0.19$ & $8.07 \pm 0.08$ & $1.18 \pm 0.02$ & $44.7 \pm 4.5^{*}$ & $0.36 \pm 0.03$ & $1.07 \pm 0.06$ & $0.69 \pm 0.04$ & $0.12 \pm 0.01$ & $2.24 \pm 0.13$ & $68.42 \pm 1.86$ & $30.5 \pm 2.0$ \\
\hline
\end{tabular}

853 Table 1. OSL datings performed in Amiens-Renancourt 1 excavation. U, Th and K: elemental 854 concentrations measured by gamma spectroscopy. W: Saturated water content. Dx: annual 855 dose rates of $\alpha, \beta, \gamma$ and cosmic radiations, and equivalent dose. *The age of sample 856 REN1 15-01 was recalculated with a more realistic water content from another sample that 857 was physically close and taken on another profile of the site. 


\begin{tabular}{|c|c|c|c|c|c|c|}
\hline Material & Laboratory code & Sample / Depth (m) & ${ }^{14} \mathrm{C}$ age $(\mathrm{BP})$ & $\begin{array}{c}\text { Calibrated age } \\
\text { (a cal BP) } \\
\text { [95.4\% } \\
\text { probability] }\end{array}$ & $\begin{array}{l}\text { Median } \\
\text { calibrated } \\
\text { age }\end{array}$ & Source \\
\hline Earthworm granules & Poz-73520 & $\mathrm{H}:-15:-10 / 3.60-3.65$ & $22190 \pm 160$ & $26036-26929$ & 26415 & this study \\
\hline Earthworm granules & Poz-73521 & $H:-30:-25 / 3.75-3.80$ & $22700 \pm 160$ & $26575-27389$ & 27032 & this study \\
\hline Earthworm granules & SacA51278 & $H:-70:-65 / 4.15-4.20$ & $23540 \pm 150$ & $27439-27907$ & 27681 & this study \\
\hline Earthworm granules & Poz-73524 & B: $-50:-45$ & $24610 \pm 200$ & $28154-29097$ & 28645 & this study \\
\hline Earthworm granules & SacA51286 & B: $-70:-65 / 4.90-4.95$ & $25220 \pm 180$ & $28811-29712$ & 29262 & this study \\
\hline Earthworm granules & SacA46563 & B: $-95:-90 / 5.15-5.20$ & $31410 \pm 400$ & $34584-36138$ & 35313 & this study \\
\hline Earthworm granules & SacA46564 & B: $-125:-120 / 5.45-5.50$ & $32540 \pm 470$ & $35472-38050$ & 36569 & this study \\
\hline Earthworm granules & ECHo-3742.1.1/GifA 20375.1 & A: $-4.20 / \sim 6.70-6.90$ & $30350 \pm 490$ & $33562-35271$ & 34366 & this study \\
\hline Earthworm granules & ECHo-3742.1.2/GifA 20375.2 & A: $-4.20 / \sim 6.70-6.90$ & $27160 \pm 350$ & $30667-31646$ & 31142 & this study \\
\hline Earthworm granules & ECHo-3742.1.3/GifA 20375.3 & A: $-4.20 / \sim 6.70-6.90$ & $39200 \pm 1400$ & $40926-45484$ & 43138 & this study \\
\hline Bone & Beta-306063 & Archaeological layer / 4.15-4.20 & $21890 \pm 90$ & $25898-26344$ & 26092 & Paris et al. (2013) \\
\hline Bone & Lyon-9943/SacA32189 & Archaeological layer / 4.15-4.20 & $22600 \pm 170$ & $26465-27333$ & 26913 & Paris et al. (2017) \\
\hline Burnt bone & Lyon-9942/SacA32188 & Archaeological layer / 4.15-4.20 & $23580 \pm 180$ & $27421-27996$ & 27708 & Paris et al. (2017) \\
\hline Charcoal & Lyon-11659/SacA39279 & Archaeological layer / 4.15-4.20 & $23250 \pm 210$ & $27158-27798$ & 27500 & Paris et al. (2017) \\
\hline Bone & Lyon-632 & \multirow{2}{*}{$\begin{array}{l}\text { Isolated bones found in unit } 5 \text { in a } \\
\text { test pit about } 100 \mathrm{~m} \mathrm{SSE} \text { of the site }\end{array}$} & $23040 \pm 220$ & $26864-27721$ & 27342 & Fagnart et al. (2013) \\
\hline Bone & Lyon-633 & & $22360 \pm 240$ & $26089-27208$ & 26647 & Fagnart et al. (2013) \\
\hline
\end{tabular}

860 Table 2. Radiocarbon datings performed in Amiens-Renancourt 1 excavation and on a bone 861 found in Renancourt 2000 test pit. Ages were calibrated with the software Calib 7.0.4 (Stuiver \& Reimer, 1993) and the IntCal13 calibration curve (Reimer et al., 2013). 


\begin{tabular}{|c|c|c|c|c|c|c|c|c|c|c|c|c|c|c|c|c|c|c|c|}
\hline $\begin{array}{c}\text { Ecological } \\
\text { groups }\end{array}$ & 2 & \multicolumn{2}{|c|}{5} & \multicolumn{3}{|c|}{7} & \multirow[b]{2}{*}{$\begin{array}{l}7^{\prime} \\
\end{array}$} & \multirow[b]{2}{*}{ 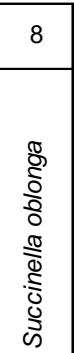 } & \multirow[b]{2}{*}{ 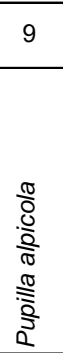 } & \multicolumn{2}{|c|}{ U } & \multicolumn{3}{|c|}{10} & \multirow[b]{2}{*}{ 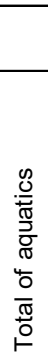 } & \multirow[b]{2}{*}{ 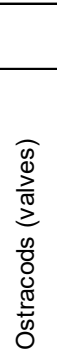 } & \multirow[b]{2}{*}{ 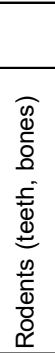 } & \multicolumn{2}{|c|}{$\begin{array}{l}\text { Molluscan } \\
\text { record }\end{array}$} \\
\hline 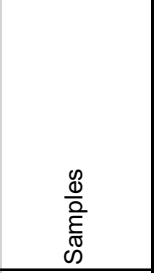 & 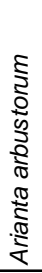 & 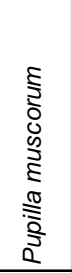 & 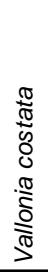 & 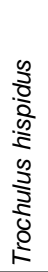 & 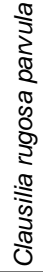 & 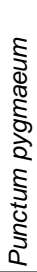 & & & & $\begin{array}{l}0 \\
\text { के } \\
\frac{\pi}{3} \\
\frac{2}{2} \\
0\end{array}$ & 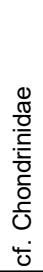 & 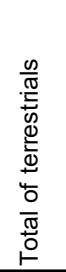 & $\begin{array}{l}\frac{\dot{\theta}}{0} \\
\frac{5}{3} \\
\frac{0}{n} \\
\frac{0}{2}\end{array}$ & 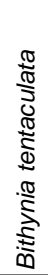 & & & & $\frac{\mathscr{0}}{\frac{0}{0}}$ & $\begin{array}{l}\mathscr{D} \\
\mathbb{D} \\
\mathbb{0} \\
\frac{\mathbb{L}}{\alpha}\end{array}$ \\
\hline $\mathrm{H}: 15: 10$ & 0 & 12 & 0 & 1 & 0 & 0 & 0 & 1 & 0 & 0 & 0 & 14 & 0 & 0 & 0 & 0 & 0 & \multirow{3}{*}{$\mathrm{C} 7$} & \multirow{3}{*}{ I } \\
\hline $\mathrm{H}: 10: 5$ & 0 & 5 & 0 & 1 & 0 & 0 & 0 & 2 & 0 & 0 & 0 & 8 & 0 & 0 & 0 & 1 & 0 & & \\
\hline$H: 5: 0$ & 0 & 12 & 0 & 2 & 0 & 0 & 4 & 10 & 9 & 0 & 0 & 37 & 0 & 0 & 0 & 2 & 0 & & \\
\hline $\mathrm{H}: 0:-5$ & 0 & 0 & 0 & 1 & 0 & 0 & 1 & 8 & 10 & 0 & 0 & 20 & 1 & 0 & 1 & 5 & 0 & \multirow{5}{*}{ C6 } & \multirow{3}{*}{$\|$} \\
\hline $\mathrm{H}:-5:-10$ & 0 & 1 & 0 & 0 & 0 & 0 & 2 & 200 & 1 & 0 & 0 & 204 & 1 & 0 & 1 & 2 & 0 & & \\
\hline$H:-10:-15$ & 0 & 0 & 0 & 0 & 0 & 0 & 3 & 438 & 0 & 5 & 0 & 446 & 1 & 0 & 1 & 2 & 0 & & \\
\hline $\mathrm{H}:-15:-20$ & 0 & 5 & 0 & 1 & 0 & 0 & 1 & 77 & 5 & 0 & 0 & 89 & 1 & 0 & 1 & 1 & 0 & & \multirow{2}{*}{1} \\
\hline $\mathrm{H}:-20:-25$ & 0 & 5 & 0 & 1 & 0 & 0 & 5 & 29 & 0 & 0 & 0 & 40 & 1 & 0 & 1 & 1 & 0 & & \\
\hline $\mathrm{H}:-25:-30$ & 0 & 0 & 0 & 1 & 0 & 0 & 5 & 91 & 12 & 0 & 0 & 109 & 2 & 0 & 2 & 4 & 0 & & $\|$ \\
\hline $\mathrm{H}:-30:-35$ & 1 & 24 & 0 & 1 & 1 & 0 & 5 & 97 & 0 & 0 & 0 & 129 & 0 & 0 & 0 & 1 & 0 & 5 & $\|$ \\
\hline $\mathrm{H}:-35:-40$ & 0 & 12 & 1 & 2 & 0 & 0 & 17 & 45 & 12 & 0 & 0 & 89 & 1 & 0 & 1 & 0 & 0 & & \\
\hline $\mathrm{H}:-40:-45$ & 0 & 24 & 0 & 1 & 0 & 0 & 9 & 98 & 0 & 0 & 0 & 132 & 1 & 0 & 1 & 4 & 0 & & 1 \\
\hline $\mathrm{H}:-45:-50$ & 0 & 16 & 0 & 0 & 0 & 0 & 18 & 488 & 24 & 0 & 0 & 546 & 1 & 0 & 1 & 3 & 0 & & \\
\hline$H:-50:-55$ & 0 & 7 & 0 & 0 & 0 & 0 & 33 & 499 & 57 & 0 & 0 & 596 & 0 & 0 & 0 & 1 & 0 & & IV \\
\hline $\mathrm{H}:-55:-60$ & 0 & 19 & 1 & 1 & 0 & 0 & 64 & 290 & 57 & 0 & 0 & 432 & 1 & 0 & 1 & 2 & 0 & & \\
\hline H: $-60:-65$ & 0 & 92 & 0 & 0 & 0 & 0 & 51 & 174 & 372 & 0 & 0 & 689 & U & 0 & 0 & 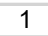 & 0 & & IIII \\
\hline $\mathrm{H}:-65:-69$ & 0 & 7 & 0 & 1 & 0 & 0 & 14 & 102 & 40 & 0 & 0 & 164 & 0 & 0 & 0 & 1 & 0 & & \\
\hline $\mathrm{H}:-70:-75$ & 0 & 162 & 0 & 1 & 0 & 0 & 131 & 1245 & 542 & 0 & 0 & 2081 & 0 & 1 & 1 & 4 & 1 & & Ila \\
\hline B: $0:-5$ & 0 & 84 & 0 & 0 & 0 & 0 & 53 & 1309 & 249 & 0 & 0 & 1695 & 0 & 0 & 0 & 2 & 0 & $\mathrm{C} 4$ & \\
\hline B: $-5:-10$ & 0 & 34 & 0 & 0 & 0 & 0 & 21 & 235 & 39 & 0 & 0 & 329 & 0 & 0 & 0 & 1 & 0 & & \\
\hline B: $-10:-15$ & 0 & 25 & 1 & 1 & 0 & 0 & 22 & 82 & 15 & 0 & 1 & 147 & 0 & 0 & 0 & 4 & 0 & & $\| s$ \\
\hline B: $-15:-20$ & 0 & 13 & 0 & 1 & 0 & 0 & 22 & 26 & 25 & 0 & 0 & 87 & 0 & 0 & 0 & 7 & 0 & & \\
\hline B: $-20:-25$ & 0 & 21 & 0 & 1 & 0 & 0 & 18 & 26 & 23 & 0 & 0 & 89 & 1 & 0 & 1 & 8 & 0 & & l \\
\hline B: $-25:-30$ & 0 & 27 & 1 & 1 & 0 & 0 & 18 & 31 & 21 & 0 & 0 & 99 & 0 & 0 & 0 & 8 & 0 & & 1 \\
\hline B: $-30:-35$ & 0 & 38 & 0 & 1 & 0 & 0 & 31 & 35 & 47 & U & 0 & 152 & 2 & 0 & 2 & 13 & 0 & & \\
\hline B: $-35:-40$ & 0 & 58 & 0 & 1 & 0 & 0 & 64 & 79 & 58 & 0 & 0 & 260 & 1 & 0 & 1 & 7 & 0 & & IV \\
\hline B: $-40:-45$ & 0 & 162 & 0 & 7 & 0 & 0 & 276 & 265 & 194 & 0 & 0 & 904 & 1 & 0 & 1 & 7 & 0 & & IV \\
\hline B: $-45:-50$ & 0 & 1320 & 0 & 28 & 0 & 0 & 503 & 791 & 1155 & 0 & 0 & 3797 & 1 & 0 & 1 & 2 & 0 & & Illd \\
\hline B: $-50:-55$ & 0 & 507 & 0 & 2 & 0 & 0 & 293 & 1590 & 1463 & 0 & 0 & 3855 & 0 & 0 & 0 & 4 & 1 & & Illh \\
\hline B: $-55:-60$ & 0 & 310 & 0 & 3 & 0 & 1 & 146 & 2055 & 699 & 0 & 0 & 3214 & 2 & 0 & 2 & 1 & 0 & & 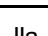 \\
\hline B: $-60:-65$ & 0 & 41 & 0 & 0 & 1 & 0 & 26 & 711 & 75 & 0 & 0 & 854 & 0 & 0 & 0 & 0 & 0 & $\mathrm{C} 3$ & Ila \\
\hline B: $-65:-70$ & 0 & 6 & 0 & 0 & 0 & 0 & 6 & 58 & 5 & 0 & 0 & 75 & 0 & 0 & 0 & 5 & 0 & & \\
\hline B: $-70:-75$ & 0 & 2 & 0 & 0 & 0 & 0 & 1 & 25 & 3 & 0 & 0 & 31 & 0 & 0 & 0 & 5 & 0 & & $\| s$ \\
\hline B: $-75:-80$ & 0 & 6 & 0 & 0 & 0 & 0 & 2 & 17 & 2 & 0 & 0 & 27 & 0 & 0 & 0 & 0 & 0 & & \\
\hline B: $-80:-85$ & 0 & 6 & 0 & 0 & 0 & 0 & 0 & 13 & 4 & 0 & 0 & 23 & 0 & 0 & 0 & 0 & 0 & & 1 \\
\hline B: $-85:-90$ & 0 & 7 & 0 & 0 & 0 & 0 & 0 & 6 & 5 & 0 & 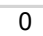 & 18 & 0 & 0 & 0 & 4 & 0 & & \\
\hline B: $-90:-95$ & 0 & 11 & 0 & 0 & 0 & 0 & 7 & 3 & 18 & 0 & 0 & 66 & 0 & 0 & 0 & 0 & 0 & & \\
\hline B: $-95:-100$ & 0 & 4 & 0 & 0 & 0 & 0 & 2 & 20 & 16 & 0 & 0 & 42 & 0 & 0 & 0 & 2 & 0 & & $\|$ \\
\hline B: $-100:-105$ & 0 & 4 & 0 & 3 & 0 & 0 & 0 & 6 & 5 & 0 & 0 & 18 & 0 & 0 & 0 & 1 & 0 & רי & \\
\hline B: $-105:-110$ & 0 & 17 & 0 & 1 & 0 & 0 & 7 & 1 & 3 & 0 & 0 & 29 & 0 & 0 & 0 & 2 & 0 & $\mathrm{j} 2$ & \\
\hline B: $-110:-115$ & 0 & 20 & 1 & 1 & 0 & 0 & 6 & 1 & 18 & 0 & 0 & 47 & 0 & 0 & 0 & 1 & 0 & & 1 \\
\hline B: $-115:-120$ & 0 & 29 & 0 & 1 & 0 & 0 & 10 & 3 & 33 & 0 & 0 & 76 & 0 & 0 & 0 & 1 & 1 & & \\
\hline B: $-120:-125$ & 0 & 66 & 1 & 2 & 0 & 0 & 42 & 9 & 87 & 0 & 0 & 207 & 1 & 0 & 1 & 0 & 0 & & IV \\
\hline B: $-125:-130$ & 0 & 71 & 0 & 2 & 0 & 0 & 93 & 20 & 432 & 0 & 0 & 618 & 0 & 0 & 0 & 1 & 0 & ;1 & III \\
\hline
\end{tabular}

865 Table 3. Molluscan taxa abundances of the Amiens-Renancourt 1 excavation. Ecological 866 groups: half-forested (2), open (5), mesophilous (7), slugs (7'), hygrophilous (8), palustral (9), 867 aquatics (10) and undetermined (U). See table 5 for the description of molluscan phase types. 


\begin{tabular}{|c|c|c|c|c|}
\hline $\begin{array}{c}\text { ECOLOGICAL } \\
\text { GROUP }\end{array}$ & TAXA & HABITAT & ECOLOGICAL REMARKS & $\begin{array}{l}\text { REMARK'S } \\
\text { AUTHOR }\end{array}$ \\
\hline $\begin{array}{l}\text { Hygrophilous } \\
\text { (8) }\end{array}$ & \begin{tabular}{|l} 
Succinella oblonga \\
(Draparnaud, 1801)
\end{tabular} & $\begin{array}{l}\text { Wet stations with a sparse vegetation (humid meadows, } \\
\text { swamps and near brooks). }\end{array}$ & $\begin{array}{l}\text { It lives on "damp mud or rock surfaces, whether on the banks } \\
\text { of rivers or lakes, or high up on screes". }\end{array}$ & Kerney (1971) \\
\hline Palustral (9) & $\begin{array}{l}\text { Pupilla alpicola } \\
\text { (Charpentier, 1837) }\end{array}$ & $\begin{array}{l}\text { Very wet mountain stations (fens with sparse vegetation, peat } \\
\text { bogs, wet grasslands), preferentially in calcareous areas. }\end{array}$ & & \\
\hline Slugs $\left(7^{\prime}\right)$ & $\begin{array}{l}\text { Limacidae Lamarck, } 1801 \\
\text { Milacidae Ellis, } 1926\end{array}$ & $\begin{array}{l}\text { Various habitats, prefrentially with clayey soils retaining } \\
\text { moisture and offering shelters and hiding places }\end{array}$ & & \\
\hline \multirow{2}{*}{$\begin{array}{l}\text { Open habitat } \\
\text { (5) }\end{array}$} & \begin{tabular}{|l|} 
Pupilla muscorum \\
(Linnæus, 1758)
\end{tabular} & $\begin{array}{l}\text { Open, dry and sunny, calcareous stations (dry meadows, } \\
\text { sand dunes). }\end{array}$ & $\begin{array}{l}\text { It tolerates "earth bare of vegetation" and "a considerable range } \\
\text { of diurnal temperature as well". }\end{array}$ & Evans (1972) \\
\hline & $\begin{array}{l}\text { Vallonia costata } \\
\text { (O.F. Müller, 1774) }\end{array}$ & $\begin{array}{l}\text { Varied open, dry and humid, stations with stones; rarely found } \\
\text { in woods or swamps. }\end{array}$ & It "prefers more stable grassland". & Kerney (1971) \\
\hline \multirow{3}{*}{ Mesophilous (7) } & $\begin{array}{l}\text { Trochulus hispidus } \\
\text { (Linnaeus, 1758) }\end{array}$ & $\begin{array}{l}\text { Various moderately dry to humid stations (flood plains, marshy } \\
\text { places, damp meadows, shrublands, light forest). }\end{array}$ & $\begin{array}{l}\text { It is qualified as "relatively thermophilous" }\left({ }^{\star}\right) \text { and considered as } \\
\text { an "early coloniser of damp broken ground before the } \\
\text { development of a binding cover of vegetation" }\left({ }^{\star \star}\right)\end{array}$ & $\begin{array}{l}\left(^{*}\right) \text { Kerney } \\
(1963) ;\left({ }^{\star *}\right) \\
\text { Kerney }(1971)\end{array}$ \\
\hline & $\begin{array}{l}\text { Punctum pygmaeum } \\
\text { (Draparnaud, 1801) }\end{array}$ & $\begin{array}{l}\text { fairly wet habitats with a developed vegetation cover (e.g. wood } \\
\text { litter). Also in open stations and poor habitats offering a } \\
\text { sufficient moisture or hiding places. }\end{array}$ & $\begin{array}{l}\text { It is "characteristic of short-turf grassland and of open habitats } \\
\text { where there is much bare ground" }\left({ }^{\star}\right) \text { and "often appear in } \\
\text { places at an early successional stage" }\left({ }^{* *}\right) \text {. }\end{array}$ & $\begin{array}{c}\left(^{*}\right) \text { Evans } \\
(1972) ;\left({ }^{* *}\right) \\
\text { Horsák et al. } \\
(2013)\end{array}$ \\
\hline & $\begin{array}{l}\text { Clausilia rugosa parvula } \\
\text { A. Férussac, } 1807\end{array}$ & $\begin{array}{l}\text { Little humid to very dry shaded open stations with rocks and } \\
\text { short vegetation. Rare in woods. Calciphile. }\end{array}$ & & \\
\hline Half-forested (2) & $\begin{array}{l}\text { Arianta arbustorum } \\
\text { (Linnaeus, 1758) }\end{array}$ & $\begin{array}{l}\text { Very wet and vegetated stations. Also in sufficiently moist } \\
\text { open stations. Cold resistant. }\end{array}$ & $\begin{array}{l}\text { "It is commoner in river valley bottoms, (..) occurs more often } \\
\text { in thick vegetation }(\ldots) \text { and it is also favoured by steep north- } \\
\text { facing slopes". }\end{array}$ & $\begin{array}{l}\text { Cameron et al. } \\
\text { (1971) }\end{array}$ \\
\hline \multirow{2}{*}{ Aquatic (10) } & \begin{tabular}{|l|} 
Pisidium \\
C. Pfeiffer, 1821
\end{tabular} & $\begin{array}{l}\text { Various habitats: (periodic) swamps, standing and flowing } \\
\text { waters }\end{array}$ & & \\
\hline & $\begin{array}{l}\text { Bythinia tentaculata } \\
\text { (Linnaeus, 1758) }\end{array}$ & $\begin{array}{l}\text { Slowly flowing waters, but also in periodic pools on muddy } \\
\text { bottom and plants when water dries out. }\end{array}$ & & \\
\hline
\end{tabular}

870 Table 4. Taxa ecological preferences synthesised after (Boycott, 1934), Ložek (1964), Kerney et al. (1983), Welter-Schultes (2012) and Horsák et al. (2013) and additional remarks. Taxa are listed by ecological groups, which are ordered by decreasing importance in the site. Taxonomical remarks: (i) while internal shells of Limacidae and Milacidae can be distinguished, they cannot be identified at the species rank; (ii) according to their finely ribbed microsculpture, the two apices of Clausilia rugosa (Draparnaud, 1801) found at AmiensRenancourt 1 were attributed to the sub-species C. rugosa parvula A. Férussac, 1807; (iii) valves and fragments of Pisidium were too few to allow for a reliable identification at the species rank; (iv) the single opercula attributed to this taxa cannot belong to another Bithynia species such as Bithynia leachii (Sheppard, 1823). 


\begin{tabular}{|c|c|c|c|c|c|c|c|c|c|}
\hline \multicolumn{2}{|c|}{ Phases (and sub-phases) } & 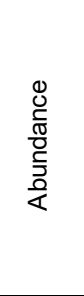 & 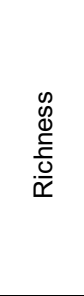 & 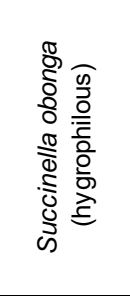 & 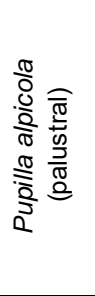 & 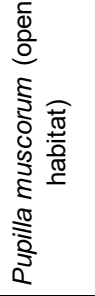 & 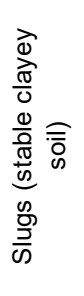 & 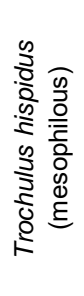 & 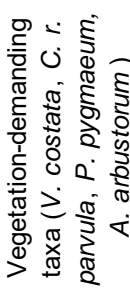 \\
\hline \multicolumn{2}{|l|}{ I: Stadial } & MIN & $(\mathrm{MIN})$ & & & & & & \\
\hline \multirow{2}{*}{$\begin{array}{l}\text { II: Stadial-interstadial } \\
\text { transition }\end{array}$} & Start & $\nearrow$ & $\nearrow$ & $\lambda(\lambda)$ & $\nearrow$ & $\nearrow$ & $\nearrow$ & $(\nearrow)$ & $(\lambda)$ \\
\hline & Acceleration & 的 & $\nearrow$ & $(\rightarrow \operatorname{MAX})$ & גית & גית & ת & $(\lambda)$ & $(\lambda)$ \\
\hline \multirow{2}{*}{ III: Interstadial optimum } & Humid & MAX & $\searrow$ & $\searrow$ & $\begin{array}{l}\lambda(\lambda) \\
\operatorname{MAX}\end{array}$ & $(\lambda)$ & $(\lambda)$ & & $(\searrow)$ \\
\hline & Dry & MAX & & $১(১)$ & $\searrow$ & $\begin{array}{l}(\nearrow) \\
\operatorname{MAX}\end{array}$ & $\lambda$ & $\lambda$ & \\
\hline \multicolumn{2}{|c|}{ IV: Interstadial-stadial transition } & $\Delta\rangle(\searrow)$ & & $১(১)$ & $\downarrow(১)$ & $\searrow(১)$ & $\begin{array}{l}\searrow(১) \\
\operatorname{MAX}\end{array}$ & $(\searrow)$ & \\
\hline
\end{tabular}

882 Table 5. Definition criteria of molluscan phases identified at Amiens-Renancourt 1. Symbols 883 are bracketed when changes do not systematically occur. 
885 Figure 1. Location of Amiens-Renancourt 1 site and of other sites mentioned in this study. 886 Legends: ice caps (light blue), modern coast lines (dashed lines), palaeo-coastlines at $-120 \mathrm{~m}$ 887 (plain line) around $27 \mathrm{ka}$ according to Clark et al. (2009), elevation (level curves every $200 \mathrm{~m}$ 888 from -120 m). Map realised with GMT 6 (Wessel et al., 2019) using a Mercator projection.

889 Figure 2. Local topographical context of the Amiens-Renancourt 1 site. Altimetry in metres 890 NGF. The asterisk indicates the position of the Renancourt 2000 test pit. Map realised with 891 version 3.4 of QGIS software (http://www.qgis.org) using the IGN BD Alti ${ }^{\circledR}$ at $5 \mathrm{~m}$.

892 Figure 3. Pedostratigraphical record of Amiens-Renancourt 1 excavation with positions of all

893

894

895

studied samples. The typology of pedological horizons follows the IUSS Working Group WRB (2015). H: upper profile; B: lower profile. Samples marked with a cross were not analysed due to the strongly reworked facies of the units concerned.

Figure 4. Granulometry, chronology and chronostratigraphy of the Amiens-Renancourt 1 loess sequence and correlations with the Nussloch loess sequence. Ages are laterally spaced according to their respective depths, except those of the archaeological layer that are artificially scattered on both sides of ${ }^{14} \mathrm{C}$ age $\mathrm{H}$ : -70 :-65 for a better readability. ${ }^{14} \mathrm{C}$ ages Lyon-632 and Lyon-633 come from another profile (see table 2 and part 4.2). Rejected ages are marked by a dashed contour; they include H3 not figured. GI: Greenland interstadials. ET: Eltville tephra; LS: Lohne soil. Correlations between the Nussloch pedostratigraphy and the NGRIP were established in Moine et al. (2017). Dashed lines highlight correlations that are not supported by ${ }^{14} \mathrm{C}$ ages.

Figure 5. Diagrams of molluscan taxa absolute and relative abundances, and curves of several molluscan population parameters. Asterisks highlight successive specific abundance maxima.

Figure 6. Correlations between molluscan fauna parameters and grain size index variations of Amiens-Renancourt 1 and Nussloch loess sequences. NGRIP data: Rasmussen et al. (2014).

Figure 7. Correlation attempt between Amiens-Renancourt 1 molluscan phases and stadialinterstadial cycles. NGRIP data: Rasmussen et al. (2014). 7H (Sieben Hengste) data: Luetscher et al. (2015). The dashed vertical line symbolizes the equilibrium between the Mediterranean (depleted values) and the North Atlantic (enriched values) advection. NGRIP and $7 \mathrm{H}$ signals have been averaged to fit with the resolution ( $\sim 100$ years per sample) of Amiens-Renancourt 1 proxies. 

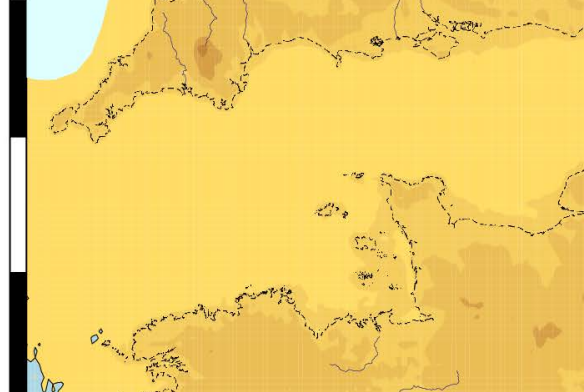

\section{Villiers-Adam}

\section{Kesselt}

\section{Amiens-Renancourt}

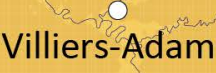

Nussloch

Sieben Hengste

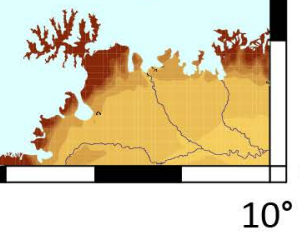




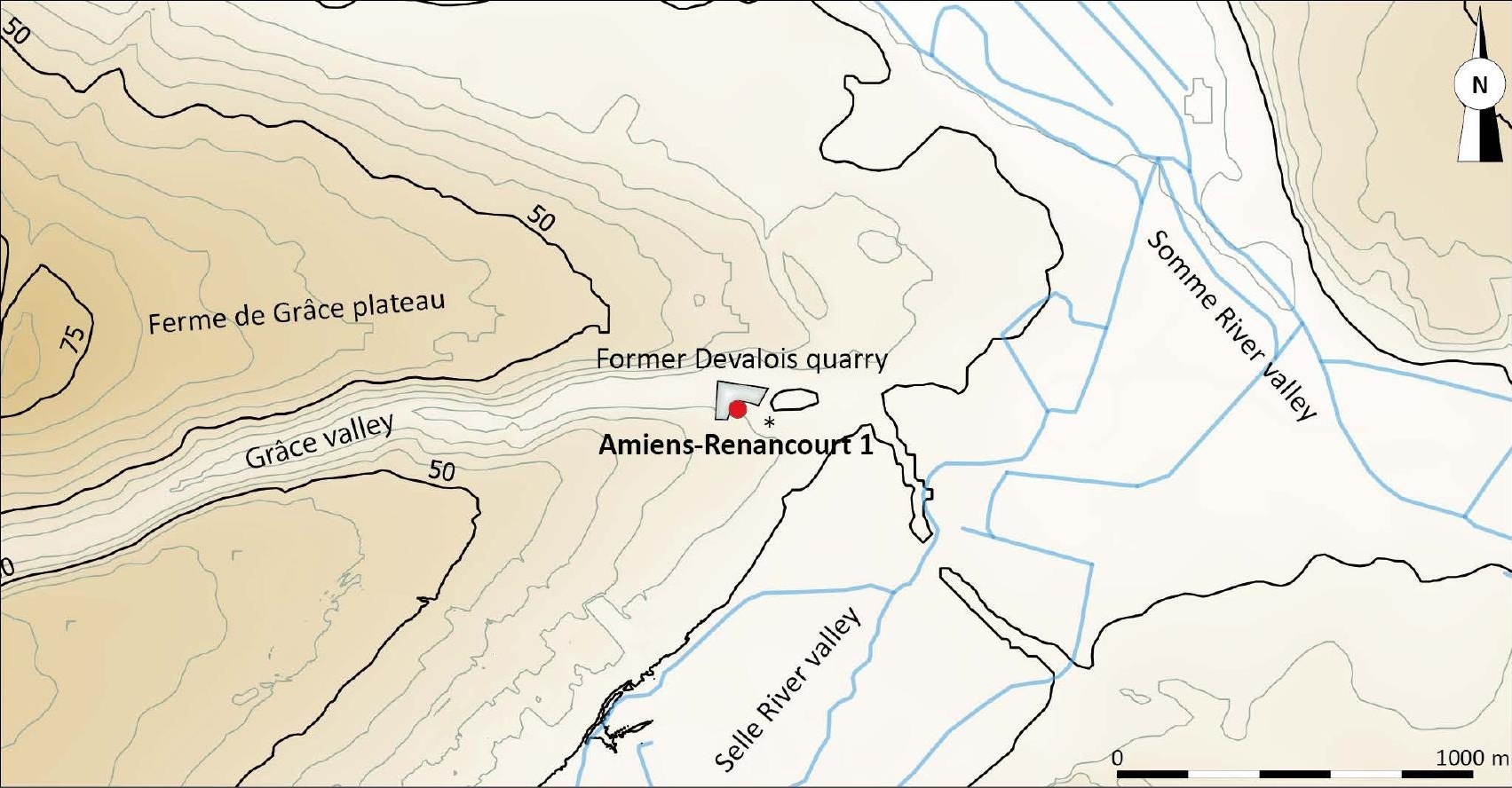




\section{Stratigraphy $\quad$ Sub-sequences}

Unit \# - Pedolithological description (interpretation)

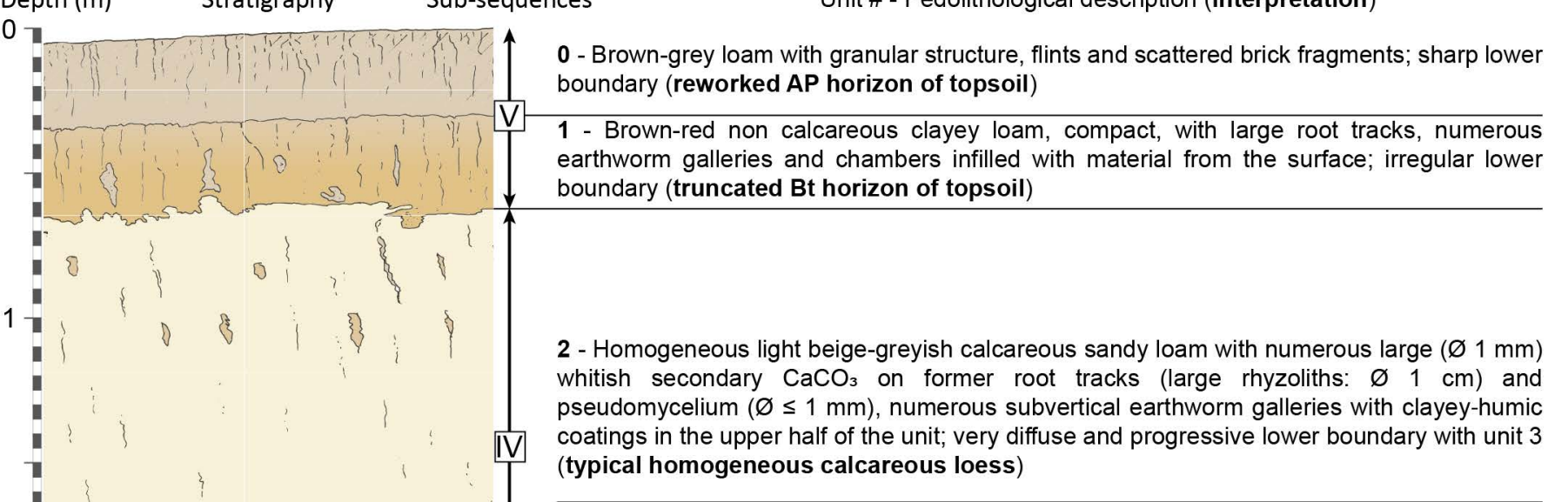

2 - Homogeneous light beige-greyish calcareous sandy loam with numerous large $(\varnothing 1 \mathrm{~mm})$ whitish secondary $\mathrm{CaCO}_{3}$ on former root tracks (large rhyzoliths: $\varnothing 1 \mathrm{~cm}$ ) and pseudomycelium $(\varnothing \leq 1 \mathrm{~mm})$, numerous subvertical earthworm galleries with clayey-humic (typical homogeneous calcareous loess)

3 - Homogeneous grey-brownish slightly humic loam with numerous secondary $\mathrm{CaCO}_{3}$ precipitation around root tracks $(\varnothing 2-5 \mathrm{~mm})$, pseudomycelium $(\varnothing \leq 1 \mathrm{~mm})$ and scattered calcareous concretions $(\varnothing 1-2 \mathrm{~mm})$ at the base; fairly sharp but deformed lower boundary with locally the presence of a 0.5 -m-deep ice-wedge cast strongly disturbed (slightly humic tundra gley horizon with gelifluction tongues)

4 - Light brown yellow calcareous sandy loess with rare sandy beds and micro-cracks deforming laminations, and scattered small ferro-manganese black patches; sharp lower boundary underlined by a gravel bed of small gelifracted flints $(\leq 1 \mathrm{~cm})$ and chalk granules (calcareous loess with a few sand beds and cryodesiccation micro-cracks)

5 - Compact brown-yellow calcareous laminated sandy loam with thin light grey beds (1-2 $\mathrm{mm})$ and micro-cracks deforming laminations; a discontinuous layer of gelifracted flint and chalk granules separates this layer in two parts; clear lower boundary associated with microcracks (laminated calcareous sandy loess with cryodesiccation micro-cracks)

6 - Thin greyish loam with orange oxidised bands and stains and ferro-manganese concretions at the base; diffuse lower boundary (thin tundra gley)

7 - Homogeneous grey-beige calcareous loam with scattered pseudomycelium (typical homogeneous calcareous loess); presence of a thin diffuse horizon with oxidation stains in the median part (micro-gley)

8 - Light grey-yellow loam with greyish patches (hydromorphy) and subvertical orange oxidised lines underlined former root tracks and ferro-manganese concretions at the base; irregular lower boundary (tundra gley)

9 - Dense homogeneous beige-light grey calcareous loam with scattered ferro-manganese concretions $(\varnothing<1 \mathrm{~mm})$ (typical homogeneous calcareous loess)

10 - Compact homogeneous brownish to brown-greyish calcareous loam with scattered small chalk granules and gelifracted flints; abundant pseudomycelium and numerous small ferro-manganese patches at the top; diffuse lower boundary (slightly brownish horizon I weakly developed arctic brown soil)

11 - Compact homogeneous light brown loam with rare scattered chalk granules and a few pseudomycelium; diffuse lower boundary (typical homogeneous calcareous loess); presence of a thin diffuse horizon with oxidation stains in the median part (micro-gley)

12 - Yellowish sandy loam with rather deformed greyish and orange beds and with numerous layers of chalk granules and scattered small gelifracted flints $(\sim 5 \mathrm{~mm})$ reworked from the slope by hillwash processes (geliflucted tundra gley complex incorporating chalk granules and gelifracted flints originating from the nearby slope)

13 - Compact yellowish calcareous loam with sandy beds and rare chalk granules; base not reached (loess reworked by hillwash processes)

An auger survey (A) performed at the base of the profile revealed the presence of $1.7 \mathrm{~m}$ of sediment with a similar facies including increasing quantities of chalk granules and gelifracted flints in the lowermost $40 \mathrm{~cm}$ (only the upper metre is represented); the base of this unit lies 8.3-m-deep on a compact gravel of gelifracted flints on the top of which the borehole was stopped A: $0-20$ 


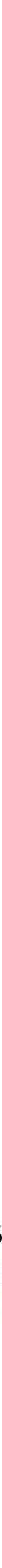




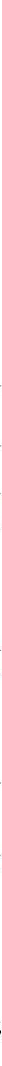




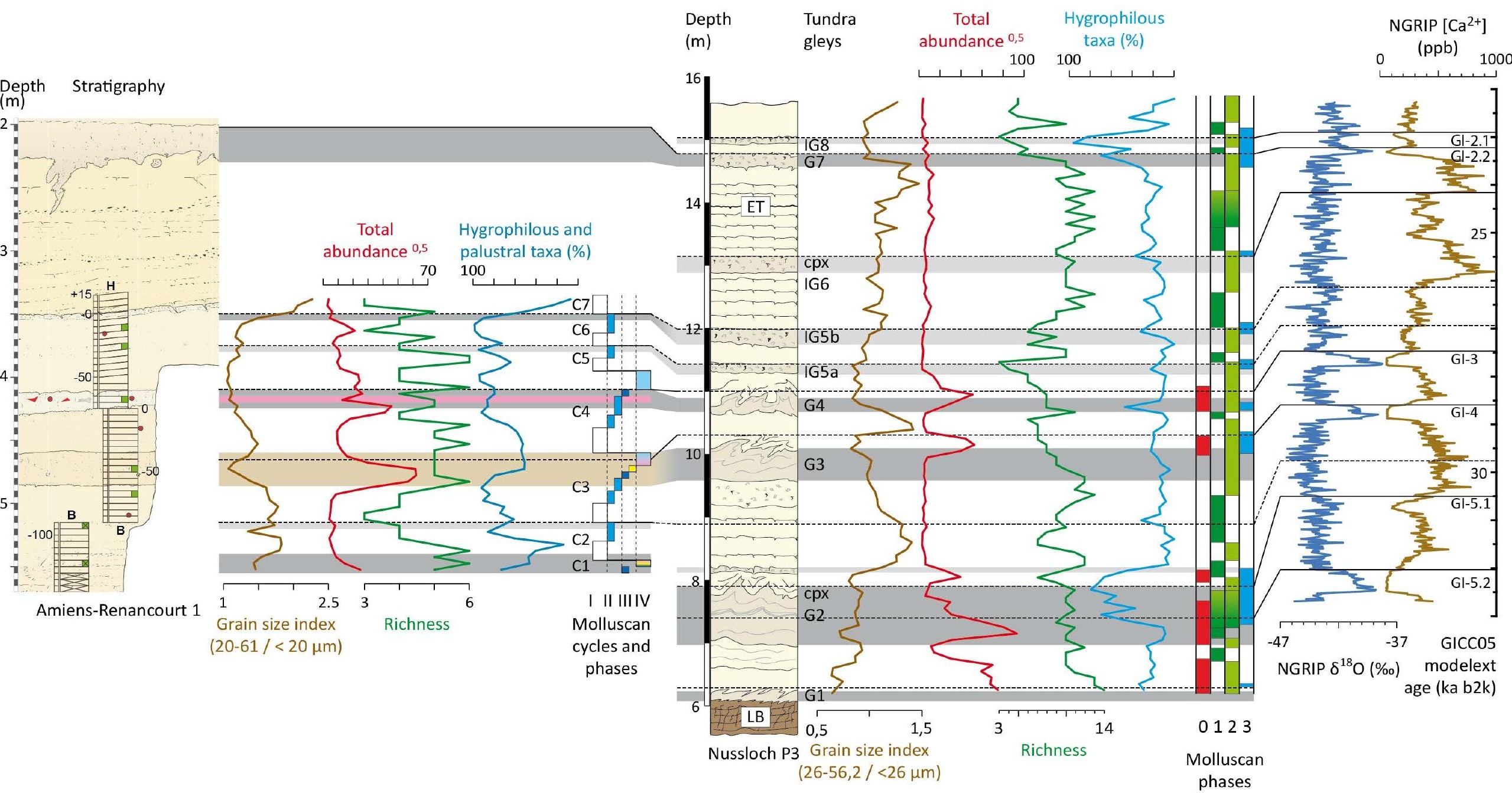




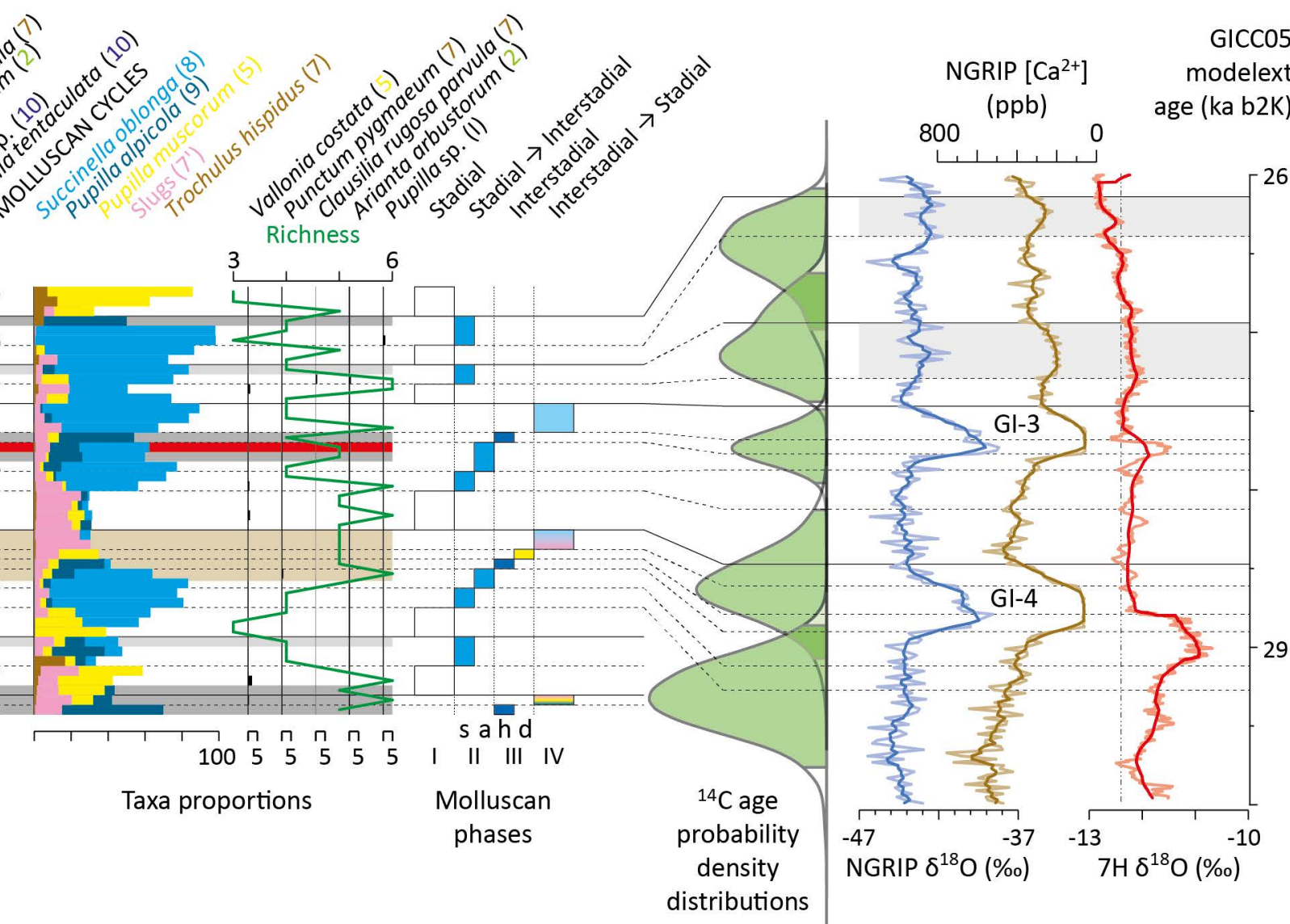

